\title{
Değerler Eğitiminde Klasik Türk Edebiyatı Metinlerinden Faydalanmak: Manzum Nasihatnameler Örneği
}

\section{Use of Classical Turkish Literature Texts in Values Education: A Case of Poetic Nasihatname}

\author{
Erkan AKALIN, Sorumlu Yazar, Dr. \\ T.C. Milli Eğitim Bakanlığı, Ankara / Türkiye. \\ erkan_06sebnem@hotmail.com \\ https://orcid.org/0000-0002-8247-5661
}

ISSN: 1303-880X

e-ISSN: 2667-7504

http://ded.dem.org.tr

Makale Türü / Article Type:

Araştırma Makalesi / Research Article

Geliş Tarihi / Received Date: 26.10.2020

Kabul Tarihi / Accepted Date: 23.05.2021

Yayın Tarihi / Published Date: 25.06.2021

Tr/En: $\operatorname{Tr}$

Intihal / Plagiarism: Bu makale, en az iki hakem tarafindan incelendi ve intihal içermediği teyit edildi. / This article has been reviewed by at least two referees and scanned via a plagiarism software.
Atıf/Citation: Akalın, E. (2021). Değerler eğitiminde Klasik Türk Edebiyatı metinlerinden faydalanmak: Manzum nasihatnameler örneği. Değerler Eğitimi Dergisi,19 (41), s.79-128. https://doi.org/10.34234/ded.816307 
Öz: Bu araştırmada nasihatname türünde kaleme alınan eserlerin, Ortaöğretim Türk Dili ve Edebiyatı Dersi (9, 10, 11 ve 12. Sınıflar) Öğretim Programı'nda yer alan adalet, dürüstlük, sabır, saygı, yardımseverlik gibi evrensel değerlerin genç nesillere aşılanmasında önemli bir kaynak olabileceği vurgulanmak istenmiştir. Örneklem olarak Vasiyyet-i Nûşirevân-1 Âdil Be-Püsereş Hürmüz-i Tâcdâr, Şeyh Eşref b. Ahmed Nasihat-nâmesi, Pendnâme-i Emîrî Çelebi, Hayriyye, Lutfiyye ve Pend-nâme-i Lokman Hekim Terceme-i Manzumesi isimli altı manzum nasihatname belirlenmiş ve bu metinler üzerinde betimsel analiz yapılmıştır. Araştırmada bu dokümanların incelenmesinin başlıca nedeni müelliflerin eserlerini doğrudan çocukları, kimilerinde kendi evlatlarını muhatap alarak nazmetmeleridir. Çalışma kapsamında incelenen dokümanların sağladığ1 veriler göstermektedir ki XIII-XIX. yüzyıllarda kaleme alınan klasik Türk edebiyatına ait metinler, evrensel değerleri aktarmaya yönelik nasihat içeriği bakımından oldukça zengin bir malzemeye sahiptir ve bu bağlamda nasihatnamelere hususi bir yer açmak gerekir. Çünkü nasihatnamelerin temel yazılış nedeni aşkın değerleri doğrudan veya ima, gönderme, kıssadan hisse yoluyla muhataba hatırlatma, öğretme, benimsetme; muhatapların değerleri hayatlarına tatbik etmelerini, sonraki kuşaklara nakletmelerini ve böylece değerli insanlar olmalarını temin etmedir. Klasik Türk edebiyatı metinlerinin; bugünün çocuklarının ilgi ve gereksinimleri, söz dağarcıkları ve idrak düzeyleri ölçüt alınıp itinalı bir planlama, inceleme, belirleme ve sınıflama sürecinden geçirilmek suretiyle yüce değerlerin taze dimağlara aktarımında oldukça etkili bir eğitim ve öğretim gereci olarak kullanılabileceği düşünülmektedir.

Anahtar kelimeler: Klasik Türk edebiyat,, Manzum nasihatnameler, Evrensel değerler, Değerler eğitimi.

$\&$

Abstract: This study aims to underline the extent to which books written as nasihatname genre can serve as an important source for immersing young generations with some universal values like justice, honesty, patience, respect and helpfulness which take place in the Secondary Education Turkish Language and Literature subject (9th, 10th, 11th and 12th grades) Curriculum. Six nasihatnames in verse, Vasiyyet-i Nûşirevân-1 Âdil Be-Püsereş Hürmüz-i Tâcdâr, Şeyh Eşref b. Ahmed Nasihat-nâmesi, Pendnâme-i Emîrî Çelebi, Hayriyye, Lutfiyye and Pend-nâme-i Lokman Hekim Terceme-i Manzumesi, were chosen as sample and these texts were analysed descriptively. Main reason for examining these documents in the study is that the authors allocated their works directly for children and some of them did 
that specifically for their own kids. The data collected from the documents which were examined for the study shows that the texts in classical Turkish Literature written in XIII-XIX centuries have a highly rich content regarding their content for conveying universal values and in this context, it's necessary to expand space for the nasihatnames in classrooms. The main reason for writing nasihatnames is to remind, to teach and to adopt the transcendent values explicitly or implicitly, by referring or pointing to a moral significance of an action; in addition, they help the audience apply the values in their lives, transfer the values the next generations and thus make them virtuous people. This study suggest that the texts of Classical Turkish Literature can be used as a quite effective educational tool for transferring values to the young minds with careful planning, studying, determining, and classifying process which is proper for the interests, needs, and the level of perception of today's children.

Keywords: Classical Turkish Literature, Nasihatnames in verse, Universal values, Values education.

(The Extended Abstract is at the end of the article)

\section{Giriş}

Hangi çağa, coğrafyaya ve insan topluluğuna gidilirse gidilsin kıymetli bulunan; zamanı aşan; bununla beraber ideal insan ve toplum olmanın gereği addedilen ve adalet, dostluk, dürüstlük, öz denetim, sabır, saygı, sevgi, sorumluluk, vatanseverlik, yardımseverlik gibi özelliklerin oluşturduğu dizgeye "evrensel (yüksek, aşkın) değerler” denir. Evrensel değerler insanın ve toplumun münasip olup olmadığını belirleyen temel kriterdir. Kişi veya halk bu değerlerin icaplarına uygun, erdemli tutum ve davranışlar sergilediği ölçüde makul ve makbul bulunur; bireyin ya da toplumun mutlu ve huzurlu olacağına inanılır.

Başka bir deyişle değerler, insanoğlunun tarihten bugüne kabul ettiğii, sosyal öğrenme yoluyla mutlaka benimsetilmesi gereken ortak kavramlar olup bir anlamda saadetin standartlar kümesidir. Kişi saadete ancak öğrendiği erdemler vasıtasıyla ulaşır (Tarhan, 2019). Bu nedenledir ki insan gerek iç huzuru gerekse toplumsal barışı sağlamak üzere aşkın değerler üreten ve ürettiği değerlere riayet etmeyi önemseyen bir varlıktır.

Diğer taraftan dikkat, bugüne -hız, haz ve hırsın yavaşa, aza, öze ve tokgözlülüğe egemen olmaya çalıştığ 1 XXI. yüzyıla- çevrildiğinde bilhassa gençler üzerinde enikonu palazlanan vurdumduymazlık, aidiyet duygusunda çözülme ve beraberinde gelen köksüzlük, kimliksizlik, dünyada topyekûn hissedilen değer 
aşınması veya değer yitimi, bir karş1 güç olarak günbegün değerler eğitiminin önemini artırmaktadır.

Peki, evrensel değerler hangi tedbir ve uygulamalarla yerini koruyabilir yahut insan ruhunda ve toplumsal şuurda nasıl sağlklı ve süreğen bir yer edinebilir?

Her ne kadar insanın doğasında bu aşkın değerlerin potansiyel olarak var olabileceği düşünülse de bu cevheri uygun bir şekilde ortaya çıkarmak, güçlü ve devamlı kılmak üzere birtakım uygulamalara başvurulur: Değerlerin korunması ve değerlere uyulması yönünde hukuki düzenlemeler yapılır, kanuni dayanaklar oluşturulur; bu değerlere temas eden fikir ve fiiller halk arasında teşvik ve tebrik edilir, aykırı hâl ve hareketler ayıplanır, tenkit edilir. Bu değerlerin millî-manevi değerlerle örtüşen noktalarl; çocuğun kendini, kendi gibileri, kendince ve kendi kültürünce ideal olanı tanımasını sağlayacak çeşitli yaşam durumları içeren dinî-tasavvufi-menkıbevi, tarihî, felsefi, edebî metinlerle; türlü atasözü ve özdeyişle devamlı olarak hatırlatılır, tekrarlanır. Örneğin Yûsuf Has Hâcib'in insana her iki dünyada saadete ermek için takip edilecek yolu göstermek amacyyla kaleme aldığı sembolik ve diyalog temelli nasihatnamesi Kutadgu Bilig'in kahramanlarından Vezir Ay Toldı, oğlu Ögdülmiş’e çocuk yetiştirme hususunda şöyle nasihat etmektedir: Kimin çocukları naz içinde yetiştirilirse o kimseye ağlamak düşer; keder ona mukadderdir. Baba çocuğunu küçüklüğünde başıboş bırakırsa kabahat ve suç çocukta değil babadadır. Çocukların tavrı, hareketi kötü ise o kötülüğü baba yapmıştır. Çocuğu iyi olmaktan mahrum eden odur. Baba çocuğunu sıkı bir terbiye altına alıp ona her şeyi öğretirse çocuğu yetişip büyüyünce sevinir. Ey baba, çocuğunu sıkı terbiye et ki arkadan gelenler sana gülmesinler. Çocuklara erdem ve bilgi öğretmeli ki onlar iyi ve güzel yetişsinler (Kaçalin, 2020).

Evrensel değerleri kişisel ve toplumsal bellekte zinde tutmak, bireyin ve toplumun aşkın değerlere uymak bakımından duyarlı bir tavır benimsemesini sağlamak adına sarf edilen gayretlerin en elverişli ve etkin yollarından biri bu değerlere dair ilke ve anlatıların eğitim programları, öğretim programları, öğrenme öğretme ortamları, eğitim araç gereçleri, ders dış1 etkinlikler, eğitim mevzuatı gibi unsurlardan oluşan eğitim sisteminin tüm hücrelerine sirayet etmesidir.

Nitekim insan ancak eğitimle insan olabilir. O her ne olmuşsa eğitim sayesinde olmuştur. Bazı şeyler insana eğitimle verilir bazı şeylerse ancak eğitimle geliştirilir. İnsan tabiatının mükemmeliyetinin büyük sırrı eğitimde saklıdır. İyi eğitim sayesinde dünyadaki iyilik adına olan her şey görünür hâle gelir. Bunun 
için gerekli olan tek şey insanda gizli hâlde bulunan nüvelerin giderek daha fazla geliştirilmesidir çünkü rüşeym hâlindeki kötülük tohumları insanın tabii eğiliminde bulunmayacaktır. Kötülük sadece denetim altına alınmamış tabiatın sonucudur. İnsanda sadece iyinin nüvesi vardır (Kant, 2020).

İdeal insanın; adalet, dürüstlük, sabır, saygı, yardımseverlik ve cömertlik gibi ulvi hasletlere sahip olan insandan sadır olabileceği; insanın bu ruhsal olgunluğa erişmesinin; erdemli, ahlaklı, edepli bir ferde dönüşmesinin ancak iyi planlanmış eğitim süreçleriyle hayata geçirilebileceği ve aşkın değerlerin özellikle çocukluk ve gençlik çağında muhtelif yaşam senaryoları biçiminde ve bir daha silinemeyecek seviyede insan zihnine işlendiği anlayışına uygun olarak Millî Eğitim Bakanlığı evrensel değerlerin genç zihinlere aktarımı hususuna özel bir önem atfetmektedir. Bu hassasiyetin bir göstergesi olmak üzere $1739 \mathrm{Sa}-$ y1lı Millî Eğitim Temel Kanunu'nda (1973) “Türk Milletinin bütün fertlerini... Türk milletinin millî, ahlaki, insani, manevi ve kültürel değerlerini benimseyen, koruyan ve geliştiren... yurttaşlar olarak yetiştirmek." şeklinde genel bir amaç ifade edilmektedir.

Bilgi, beceri ve yetkinlik ile beraber kazandırılması hedeflenen yüksek değerler ile onların çeşitli ölçülerde karışmasıyla şekillenen millî-manevi (kültürel) değerlerin fertler tarafindan kabullenilmesi konusunda benzer bir yaklaşım Ortaöğretim Türk Dili ve Edebiyatı Dersi $(9,10,11$ ve 12. Sınıflar) Öğretim Programı'nda (2018) da yer almaktadır. Öğretim Programı'na göre eğitim sistemimizin temel hedefi değerlerimizle bütünleşmiş bilgi, beceri ve davranışları haiz vatandaşlar yetiştirmektir. Bilgi, beceri ve davranışlar öğretim programlarıyla edindirilmeye çalış1ırken değerler bunlar arasındaki bütünlüğü sağlayan kavşak noktası görevi görmektedir. Değerler, toplumun kültürel kaynaklarından süzülerek geçmişten bugünlere erişmiş ve geleceğe aktarılması gereken bir mirastır.

Değerler denen prensipler bütünü temel insani özelliklerimizi meydana getirmektedir. Onlar, hayatın akışı içinde karşılaşılan problemlerle baş etmede harekete geçmemizi mümkün kılan kuvvetin membardır. Bir medeniyetin yarınlarının, evrensel ve kültürel değerlere bağlı erdemli vatandaşlarına bağlı olduğu tartışılmaz bir hakikattir. Bu itibarla eğitim sistemleri her bir üyesine, ahlaka ve adaba uygun tutumlar benimseme ve bu tutumlarla örtüşen davranışlar gösterme yetkinliğini kazandırmayı amaçlar. Denebilir ki Türk eğitim sisteminin asli vazifelerinden biri toplumu dahası yeryüzünü zaman üstü, evrensel değerlerle teçhiz olmuş bireylerden oluşan bir mekâna dönüştürmektir.

Tüm eğitim sürecinin nihai amacı ve ruhu olarak anlaşılmasına; kuşatıcı bir küme olarak düşünülmesine bağlı olarak değerler; ayrı bir program veya öğ- 
renme alanı, ünite, konu vb. olarak görülmemiş, tıpkı diğer öğretim programlarında olduğu gibi Ortaöğretim Türk Dili ve Edebiyatı Öğretim Programı'na serpilmiştir. Bu bağlamda Ortaöğretim Türk Dili ve Edebiyatı Öğretim Programı'nda adalet, dostluk, dürüstlük, öz denetim, sabır, saygı, sevgi, sorumluluk, vatanseverlik ve yardımseverlik kök değerler olarak belirlenmiş; Öğretim Programı, bu değerlerin öğrenme öğretme sürecinde gerek kendi başlarına gerekse ilişkili oldukları cömertlik, cesaret, gayret, sadakat, utanma, alçakgönüllülük, samimiyet, kanaatkârlık, merhamet, affedicilik, fedakârlık, hoşgörü gibi başka değerlerle birlikte ele alınarak hayata geçirilmeleri esasına dayandırılmıştır.

Yeni nesillerin sözü edilen yüce değerlerle donanmış faziletli insanlar olması noktasında, öğretim programlarının uygulayıcısı konumundaki eğitimcilerin en önemli ders gereçlerinden biri mesel (özlü söz söyleme), masal (benzeşim, ilişki kurma), misal (örnek verme, kıssadan hisse çıkarma) gibi usullerle, ayet ve hadis iktibasları ile değer telkin eden nasihat metinleridir.

Örneğin ilk Türk-İslam eserlerinden biri olup Türk yazı dillerinin, lehçelerinin ve ağızlarının dil özelliklerinin belirlendiği, söz varlığının derlenerek bir araya getirildiği Dîvânu Lugâti’t-Türk’te öğüt, atasözü dinlemenin önemi ve yararı şu şekilde ifade edilmektedir: "Oğul, benden öğüt al ve erdem dile ki ulus içinde ulu bir bilge olup bilgini yay... Bilginlerin sözlerini öğüt olarak al... İyi söz tesir ederse öze siner.” (Atalay, 1985).

Birçok öğüdün art arda dizildiği nasihat metinlerinin ne olduğu, niçin kaleme alındığ1; çocuğa terbiye verme, onu ahlaka ve adaba aykırı davranmaktan imtina eden erdemli bir ferde dönüştürme noktasında nasıl bir işlevinin olduğu, hangi amaçla yazıldığı konusunda Vasiyyet-i Nûşirevân-1 Âdil Be-Püsereş Hürmüz-i Tâcdâr yazarı Ahmed-i Dâ'î şunları söyler: Nasihatler, onlara uyma sürecinde başlangıçta zehir gibi acıtıcıdır. Ancak bu acı, nasihatlerden nasibini alanlar için zamanla bala dönüşecek; verilen öğütlere uyan kişi yaşı küçük olsa da zamanla ulu bir zat hâline gelecek, talih bulacak, ideallerine ulaşacaktır (Yeniterzi, 2006).

Şeyh Eşref b. Ahmed ise muhatabına nasihat sözünü iyi, güzel bir şekilde kavrarsa şüphesiz kurtuluşa ereceğini bildirmektedir (Pehlivan, 2001).

Klasik Türk edebiyatının zirve şahsiyetlerinden biri ve bu edebî anlayışta mühim bir yaklaşımın -hikemî (öğretici) üslubun- kurucusu kabul edilen 17. yüzyıl şairi Yusuf Nabi, Hayriyye'sinde (2009) evladının, fikir kazması ile kazıp kalem gereciyle araştırarak ve gönül madeninden çıkardığı taze cevherleri şiir ipliğine boydan boya dizerek oluşturduğu nasihat dizisini kulağına küpe etmesi- 
ni, verdiği öğ̈̈tleri kendisine akıllıca bir sermaye yapmasını amaçladığını ifade etmektedir.

Ahmed Râşid'in Pend-nâme-i Lokman Hekim Terceme-i Manzumesi adlı eserinde ise nasihat etme ile ilgili en temel ilkenin altı çizilir: Nasihat edenin ettiği nasihate uygun davranması, nasihin muhatap için iyi bir model olması. Kişi önce kendi aklını ve ruhunu ziynetlendirmeli ki diğer insanları da nasihatleri ile doğru yola davet edebilsin. Aksi hâlde durumu insanları temizlemekle görevli hamamcının ocağı 1sıtmasından dolayı kendi yüzünün siyah olmasına benzeyecektir. O hâlde kişinin yapıp etmeleri söylediği ögütlere uygun olmalı, külheni (ocağı) yakan gibi başkalarını temizlemeye çalışırken kirli kalmamalıdir (Kayaokay, 2018). ${ }^{1}$

Bir eğitimcinin yahut daha genel bir bakışla Millî Eğitim Bakanlığının çocuklara ve gençlere aşkın değerleri aktarmak ve benimsetmek noktasında gerek metin sayısı gerek içerik zenginliği gerekse dil zarafeti bakımından temel başvuru kaynaklarından belki de ilki klasik Türk edebiyatı metinleri olmalıdır. Nitekim kelimenin terim anlamını bir kenarda tutmak kaydıyla klasik Türk edebiyatında muhteva itibarıyla nasihatname (pendname) hüviyeti taşıyan kimi kısa (Zâtî’nin Pend-nâme-i Zâtî-i Remmâl'i), kimi uzun (Âşı Paşa'nın Garibname'si); kimi manzum (Yunus Emre'nin Risaletü'n-nushiyye'si), kimi mensur (Sinan Paşa'nın Maarifname'si), kimi manzum-mensur (Sinan Paşa'nın Tazarruname'si); kimi müstakil (Ahmed Fakih'in Çarhnâme'si), kimi bir eserin belirli bir faslı ya da fasılları (Dede Ömer Ruşeni'nin Divan'ındaki birinci terci-i bend) şeklinde; kimi iletilerini doğrudan veren (Nabi'nin Hayriyye'si), kimi metaforu, alegoriyi esas alan (Derviş Şemseddin'in Dehmurg'u); kimi dinî-tasavvufi (Şemseddin Sivâsî'nin Gülşen-âbâd'1), kimi siyasi (Koçi Bey'in Risale'si),

1 Nasihatnamelerde yetişkinlere tutum ve davranışları ile çocuklara iyi birer örnek olmalarının telkin edilmesi gibi mutlu, bilgili, becerikli ve edepli bir evlat yetiştirme konusunda bugünün eğitim anlayışıyla da örtüş̧ebilen daha birçok öneriye rastlamak mümkündür. Örneğin Şeyh Eşref b. Ahmed Nasihat-nâmesi'nde muhatabına "Çocuğun işini bitirdiğinde oynamasına engel olma, onun sonunda gözyaşı dökeceği işlere yönelmesine izin verme... İlmi öyle öğret ki içtikçe kanmasın. Yükünü ağırlaştırma ki çabuk bıkmasın. Bazen çalışması için bazen de oyalanması için kalem, kâğı ve hokka ver. Düşünüp anlamını bulması için "Bu sözün anlamı nedir?" diye sor. Şunu iyi anla: Bilince şevk gelir, bilmeyenlere ise bıkkınlık (B 373, 385 ve 387-389).” Şeklinde nasihat eder. Nâbî Hayriyye'sinde muhatabına "İhsanda bulunarak çocukları sevindir. Gönüllerini alarak kalplerini mamur et (B 242)." derken Sünbülzâde Vehbî "Yaptığın iyiliği çoluk çocuğun başına kakmaktan sakın, onlara merhamet ve şefkatle davran, iyi gözle bak (B 969).” öğüdünde bulunmaktadır. Pend-nâme-i Lokman Hekim Terceme-i Manzumesi adlı eserinde ise Ahmed Râşid büyüklere dönük olarak "Evladını ilim cevheriyle süslemeye koştur ki şeref, ilim ve bilgi ile fayda bulsun. Ona ilim kazandıracak bir üstat seç ki evladına ilim ve edep öğretsin, toplumsal yasakları / kuralları göstersin. Ahlak ilmine oldukça dikkat etmeli zira ahlak güzelliği insana büyük bir yeterlilik sağlar. Zevk ve eğlenceye düşkün, müsrif kimselerden değil evlatlar, babalar dahi uzak durmalıdır çünkü bunlar birçok evladı sefil ve ağlak kılmıştır. Evladın, işinin ehli bir rehberden ayrılmayıp eğitimini alsın, böylece ilim ve terbiyeye yücelerek ulaşsın (B 88-92).” şeklinde bir yönlendirme yapmaktadır. 
kimi tıbbi (Muhyî’nin Manzume-i Tıbb'1), kimi içtimai (Âlî Mustafa Efendi’nin Mevâidü'n-nefâis fî̀ kavâidi'l-mecâlis'i), kimi ticari (Yahyâ b. Halil b. Çoban el-Burgâzî’nin Fütüvvetnâme'si), kimi ilmî (Kınalızade Hasan Çelebi’nin Ahlak-1 Alai'si), kimi edebî (Şeyhî’nin Harname'si) yönü ağır basan; kimi tercüme (Zaîfî’nin Bâğ-1 Behişt'i), kimi telif (Geyveli Güvahî’nin Pend-nâme'si); kimi basit-açık (Ahmed-i Dâ‘î’nin Vasiyyet-i Nuşirevân-1 Âdil Be Pusereş’i), kimi nispeten daha ağır-kapalı (Kâtip Çelebi'nin Düstûrü'l-amel li-1slâhi'l-halel'i) bir dile sahip çok sayıda metin mevcuttur. Üstelik bu sınıflandırma yelpazesinin bir alt başlığı olmak üzere klasik Türk edebiyatı metinlerinden Ahmed-i Dâ'̂̂’nin Vasiyyet-i Nûşirevân-1 Âdil Be-Püsereş Hürmüz-i Tâcdâr'1, Şeyh Eşref b. Ahmed'in Nasihat-nâme'si, Diyarbakırlı Emîrî'nin Pendnâme-i Emîrî Çelebi'si, Nâbî’nin Hayriyye'si, Sünbülzâde Vehbî'nin Lutfiyye'si ve Ahmed Râşid'in Pend-nâme-i Lokman Hekim Terceme-i Manzumesi gibi bazılarında doğrudan çocuklara, hatta kimilerinde (Pendnâme-i Emîrî Çelebi, Hayriyye, Lutfiyye) şairlerin kendi çocuklarına hitaben nasihat ettikleri görülmektedir.

Klasik Türk edebiyatı metinlerinde bu denli yoğun bir öğüt içeriği bulunmasına rağmen yürürlükteki Türk dili ve edebiyatı ders kitaplarında değer aktarımı noktasında klasik Türk edebiyatı metinlerinden yeterli düzeyde istifade edilmediği, bu edebî anlayış çerçevesinde kaleme alınan metinlerden olması gerekene göre oldukça az sayıda alıntı yapıldığı görülmektedir. Örneğin 9. sınıf Türk dili ve edebiyatı ders kitapları bu açıdan tarandığında Millî Eğitim Bakanlığı Yayınlarından çıkan ders kitabının masal / fabl ünitesinde Şeyhî'nin Harname'sine, biyografi / otobiyografi ünitesinde Ahdî’nin Gülşen-i Şuara'sına, mektup / e-posta ünitesinde Fuzuli'nin Şikayetnâme'sine (Yücel, Türkyılmaz ve Sağır 2019), Sonuç Yayınlarından çıkan diğer ders kitabının ise giriş ünitesinde Yunus Emre'nin birkaç dizesi, şiir ünitesinde Fuzuli, Ruhsati, Huzuri, Yunus Emre ve Zati'den birer şiir kesiti, masal / fabl ünitesinde Şeyhî'nin Harname'sine ve Gülşehri'nin Mantıku’t-Tayr'ına, biyografi / otobiyografi ünitesinde Latifi Tezkiresi'ne ve mektup / e-posta ünitesinde yine Fuzuli'nin Şikayetnâme'sine (Özcan, 2019) yer verdiği buna karşın her iki kitapta da hikâye ve günlük ünitelerinde klasik Türk edebiyatı dairesindeki bir metnin tamamının veya büyük bir kısmının işlenmediği, şiir ünitesinde ise oldukça az örnekleme yapıldığ tespit edilmiştir. Aynı şekilde Öğretim Programı gereği klasik Türk edebiyatı metinlerinin sıklıkla yer alması beklenen 10. sınıf Türk dili ve edebiyatı ders kitaplarına bakıldığında Millî Eğitim Bakanlığı yayınlarından çıkan ders kitabının giriş ünitesinde Nedim'in bir gazelinin iki beyiti, hikâye ünitesinde Yunus Emre'den bir ilahiye, Fuzuli'nin Leylâ vü Mecnun'undan bir kesite, şiir ünite- 
sinde ise ancak Fuzuli, Baki ve Nabi'den birer gazele, Nef'i'den bir kasideye, Nedim'den bir şarkıya, Süleyman Çelebi'nin Vesiletü'n-necât'ından bir kesite ve ünite ölçme ve değerlendirme çalışmalarında Fuzuli ve Hoca Dehhani’ye ait iki gazel metnine yer verildiği görülmektedir. Bir de gezi yazısı ünitesinde Evliya Çelebi'nin Seyahatname'sinden bir bölüm işlenmiştir (Karaca vd., 2019). Ögün Yayınlarından çıkan diğer ders kitabında da giriş ünitesinde klasik Türk edebiyatından özetle söz eden bir pasaj ile Fuzuli ve Nefi'den birkaç beyit, hikâye ünitesinde mesnevi türünde bir eser olan Ashab-1 Kehf Kıssası, şiir ünitesinde Yunus Emre'den iki ilahi, Ahmedi ve Baki'den birer gazel, Fuzuli'nin Su Kasidesi ve Nedim'den bir şarkı; gezi yazısı ünitesinde yine Evliya Çelebi Seyahatnamesi’nden bir pasaj (Öztürk, 2019) yer almaktadır. Bahsi geçen ders kitaplarında klasik Türk edebiyatında pek çok örneği bulunabilecek anı türünde herhangi bir metnin kullanılmamasının yine 11 ve 12 . sınıf Türk dili ve edebiyatı ders kitaplarında makale, sohbet, fikra, eleştiri, deneme, nutuk gibi fikir sunma, böylece fikir verme, yol gösterme esaslı, öğretici metin türlerinden söz edilmesine karşın bu türlerle pekâlâ ilişkilendirilebilecek birçok numune barındıran klasik Türk edebiyatına öğretici, bilgilendirici, yönlendirici metinler özelinde gerektiği kadar teveccüh etmemenin önemli bir eksiklik olduğu düşünülmektedir.

Hâlbuki Türk edebiyatının en uzun soluklu (XIII-XIX. yüzyıl) edebî ekolünün temsilcileri konumundaki klasik Türk edebiyatı sanatkârlarını yazmaya teşvik eden başlıca saiklerden biri muhataba nasihat etme, yol yordam öğretme düşüncesidir. $\mathrm{Bu}$ düşünce nush (öğüt, pend) kavramının klasik Türk edebiyatı eserlerinin ana motiflerinden biri hâline gelmesini sağlamıştır. Hatta klasik Türk edebiyatı sahasında yer alan eserler yazılış amaçları çerçevesinde incelendiğinde divan edebiyatını pekâlâ nasihat edebiyatı veya değerler edebiyatı şeklinde adlandırmak mümkündür. Yapılması gereken, oluşturulacak çalışma gruplar1 eliyle bu kıymetli kaynağın değerler ve değerler eğitimi bağlamında özenle gözden geçirilmesi; günümüz çocuklarının ilgi ve ihtiyaçları; söz varl1$\breve{g} 1$, bilgi ve alg1 düzeyleri esas alınarak belirlenen uygun metinlerden konusuna göre tasnif edilmiş bir derlem oluşturulması ve eğitim-öğretime kazandırılan bu kaynağa mevcut durumdan çok daha sık başvurulmasıdır.

Klasik Türk edebiyatının, aşkın değerler üzerinden ideal insan ve ideal toplum olabilmenin yolların hem atasözü niteliğindeki dize ve cümleleriyle hem de yönetim, eğitim, meslek adabı, günlük hayat sahneleri gibi noktalara temas eden genellikle dinî, tasavvufi, ahlaki içerikli edebî-hikemî anlatılarla gösterme hususundaki içerik zenginliği ve bu zenginliğin beliğ bir üslupla dile getirilmesi konusundaki mahareti, alanyazındaki birçok çalışmada vurgulanmıştır. 
Işıksalan (2000), klasik Türk edebiyatı ürünlerini genç kuşaklara öğreterek onların geçmişiyle köprü kurup geleceklerini daha sağlam yapılandırabilmelerini sağlamanın eğitimin görevi olduğunu belirtmekte ve klasik Türk edebiyatının bugüne kalan pek çok seçkin mısrasının yeni nesil ile tanıştırılmasının, bu görevin temel bileşenlerinden biri olduğunu dile getirmektedir. Araştırmacı klasik Türk edebiyatının berceste mısralarından oluşan, öğrencilerin kavrama kapasitelerine uygun örneklerinin bir antoloji hâline getirilerek öğrencinin yararına sunulmasını teklif etmektedir. Öztürk (2005), On beşinci yüzyılda kaleme alınan Hamdullah Hamdi'nin Yusuf ve Zeliha adlı mesnevisini değerler açısından incelediği çalışmasında dönemin dinî, ahlaki ve sosyal değerlerinin bu metindeki yansımalarını ortaya koyarak bugün benimsenen millî-manevi değerlerinin kadim payandalarına dikkat çekmiştir. Manzum nasihatnamelerin insanların eğitiminde yararlanılabilecek yardımcı kitaplar olarak önemli bir yere sahip olduğunu ileri süren Emiroğlu (2010), bu hipotezini destekleme noktasında alanyazında bilinirliği olan, özgün yirmi beş manzum nasihatnameyi, içerdikleri ve telkin ettikleri moral değerler açısından ele almaktadır. Bu eserlerdeki öğütleri, hizmet ettikleri alanlar itibarıly dinî, tasavvufi, ahlaki eğitim; karakter eğitimi; sosyal, siyasal, ekonomik eğitim; ilmî ve mesleki eğitim, sağlık eğitimi ve çocuk eğitimi şeklinde tasnif eden araştırmacı metinlerden çıkardığı adaletli, sabırlı, ağırbaşlı olmak gibi benimsenmesi istenen kırk değer ile acelecilik, bencillik ve kıskançlık gibi sakınılması gereken sekiz tutum ve davranış üzerinden bu eserlerin çocuk eğitimi açısından kıymetlerini ortaya koymak istemiştir. Kayak (2011), klasik Türk edebiyatı metinlerinin ilköğretim II. kademede kullanılabilirliğini Nabi'nin Hayriyye'sinden hareketle oluşturduğu uygulama etkinlikleri üzerinden vermeye çalışmakta ve örneklediği etkinliklerin çoğaltılması ile çocukların ayrıntılı bilgilere sahip olmasalar dahi en azından ortaöğretime geçtiklerinde böyle bir edebî sahanın varlığından haberdar olabileceğini, böylelikle hem klasik Türk edebiyatının anlam dünyasını kavramaya yönelik alt yapılarının oluşacağı hem de klasik Türk edebiyatı dairesine nüfuz etme noktasında ilgi ve heveslerinin artacağını düşünmektedir. Bayram (2012) "Değerler Eğitiminde Unutulmuş Bir Değer: Divan Şiiri ve Kültürü” başlıklı bildirisinde Devlet-i Aliyye'nin kültür mozaiğinin en önemli taşıyıcılarından biri konumundaki klasik Türk edebiyatına ait birçok dizeyi tahlil ederek klasik Türk edebiyatı metinlerinin değerler eğitimi açısından ne kadar zengin bir içeriğe sahip olduğunun altını çizmektedir. Bayram (2018), klasik Türk edebiyatı metinlerinin değerler eğitimiyle ilgili araştırmalara katkı sunma kapasitesi ile ilgili fikirlerini desteklemek, somutlaştırmak amacıyla Adlî (Sultan II. Baye- 
zid) Divanı'nı değerler eğitimi bağlamında incelediği bir diğer çalışmasında son yıllarda değerler eğitimiyle ilgili çalışmalarda gözle görülür bir artış olduğundan, özellikle Milli Eğitim Bakanlığı nezdinde değerler ve değerler eğitiminde önemli adımlar atıldığına ancak bu konuda henüz belirlenen hedeflere erişilemediği görüşündedir. Değerler eğitimi bağlamında araştırmacıların güzel olandan güzel bahseden metinleri keşfetme ve kullanma açısından elan edebiyat evreninin tüm imkânlarından faydalanamaması bu anlamda bir eksikliktir. Güzel olandan güzel bahseden metinlerden biri olarak da Adli Divanı örneği üzerine odaklanan araştırmacı bu eserde sabır, vefa, adalet, ihlas, samimiyet, tövbe, kanaatkârlık gibi değerler eğitimi bağlamında yararlanılabilecek pek çok şiir örneğini dikkatlere sunmaktadır.

XIV. yüzyılda mesnevi nazım şeklinde telif edilen Ahmedî’nin İskendername'si, Gülşehrî’nin Mantıku’t-Tayrı, Âşık Paşa'nın Garipnâme'si ve Hoca Mesud'un Süheyl ü Nev-bahar'ını, ihtiva ettikleri değer gönderimleri yönünden inceleyen Sucu (2012), araştırma sürecinde elde ettiği bulgulardan hareketle bu eserlere dair içeriklerin öğretim programlarında öğrencilere benimsetilmesi hedeflenen değerlerle örtüştüğünün dolayısıyla mesnevi nazım şekli ile yazılmış daha birçok eserin uygun birer değer aktarım aracı olarak kullanılabileceğinin altını çizmektedir. Günümüzde sosyokültürel değerlerde yaşanan bozulmanın toplumsal çöküşlere yol açabilmesinden dolayı yeni kuşağa var olandan daha güçlü bir şekilde değerler eğitimi verilmesinin gerekliliğinden söz eden Akpınar (2015), yaşadığ 1 toplumun değerlerini barındıran edebî metinlerin ve özellikle klasik Türk edebiyatı türlerinden biri olan nasihatnamelerin bu amacı gerçekleştirmede önemli bir kaynak olacağı kanaatindedir. Araştırmacı eskilerin kâmil insan yetiştirmede sıklıkla başvurdukları bir gereç olan ahlak ve adap kılavuzları olan nasihatnamelerin aslında bugünün kendini gerçekleştirmiş insan tanımlaması ile örtüştüğünü Pendnâme-i Zarîfî adlı manzum nasihatnamede yer alan dizelerin iletilerinden hareketle dile getirmektedir. Güler'in (2015), bu araştırmanın da örneklem dairesinde yer alan nasihatnamelerden Sünbülzâde Vehbî’nin “Lutfiyye-i Vehbî”sini, Schwartz'ın değer sınıflandırmasını esas alarak ele aldığı çalışmasında bu eserin başarılı olma, yetkin olma, cesur olma, yaratıcı olma, özgür olma, yardımsever olma, dürüst olma, bağışlayıcı olma gibi otuz değere atıfta bulunduğu ve bu özelliği ile değerler eğitimi hususunda işlevsel olma bakımından zengin bir muhtevaya sahip olduğu gösterilmiştir. Araştırmacıya göre eser, bugün için değerler eğitimi bağlamında uygun olmayan kısımlardan arındırılarak Türkçe eğitiminde ilköğretim öğrencilerinin istifadesine sunulmalıdır. 
Kurtoğlu (2016), "Çocuk Edebiyatında Tarihî Metinlerden Yararlanma: Âşık Paşa'nın Garibnâme'si”" isimli çalışmasında bir klasik Türk edebiyatı metni olan Garibnâme ve benzeri metinlerin çocuklara millî değerlerin kazandırılmasında nasıl katkı sağlayacağını eserden alıntıladığı dört anlatı üzerinden ortaya koymaya çalışmıs, Demir (2016) toplumsal barışa katkı sağlayacak değerlerin bireye küçük yaştan itibaren benimsetilmesine değinerek söz konusu hedefi gerçekleştirmede kullanılabilecek en önemli materyallerden birinin edebî metinler olduğunu ifade etmektedir. Bu fikrini somutlaştırmak üzere Bûstân ve Risâletü'n-Nushiyye adlı mesnevileri değerler eğitimi bakımından inceleyen araştırmacı her iki eserde de dünya ve ahiret mutluluğunu esas alan ideal bir hayatın anlatıldığı; kanaat, tevazu, cömertlik ve doğruluğun ideal yaşamın kapısını açan anahtarlar olarak nitelendirildiğini belirtmiştir. Eserlerde sıralanan erdemlerin bugünün insanının pek çok sorununun da çözümü niteliğinde olduğunu ifade eden araştırmaciya göre yeni neslin klasik edebiyatın bu iki nasihatname ile tanışması ve böylece eserlerde dünyalarını zenginleştirmeleri gerekmektedir.

Tezkireler başta olmak biyografik eserlerden yapılan çıkarımlarla on iki bin beş yüz civarında şair ve yazarın ortaya koyduğu binlerce eserle temsil edilen klasik Türk edebiyatının kültürel belleğimizin yansıması olduğunu ileri süren Solmaz'a göre (2016) bu belgeler içinde milletimizin bütün kabullerini rastlamak mümkündür. Alçak gönüllülük, sabır, vatan sevgisi gibi metinlerde sıklıkla geçen birçok değer olan yeni kuşaklara mutlaka aktarılması gerektiğini savunan araştırmacı bunun yolu olarak ortaöğretim müfredatında değerler eğitimi adı altında bir bölüm açılmasını görmekte ve lise ders kitaplarındaki klasik Türk edebiyatı metinlerinin yeniden gözden geçirilmesini ve bu edebî ekolün mahiyetine vakıf olmak bakımından öğreticilerin eğitilmesini teklif etmektedir. Mesnevî destekli değerler eğitiminin ilkokul 4. sınıf öğrencilerinin tutumlarına etkisini inceleyen Taş (2016) araştırmasında mesnevî destekli değerler eğitiminin uygulandığı deney grubu öğrencilerinin; misafirperverlik, yardımseverlik, vatanseverlik, aile birliğine önem verme ve hoşgörü değerlerine ilişkin tutumlarında uygulama öncesi ve sonrası ölçümlere göre anlamlı bir farkl1lık oluştuğu sonucuna ulaşmıştır. Araştırmacı hazırladığı etkinlikler aracılığı ile test ettiği mesnevî destekli değerler eğitimi uygulamasının olumlu tutum ve davranış kazandırmadaki etkisinden hareketle bu tarz uygulamaların farklı öğretim kademelerinde de kullanılabileceğini ileri sürmektedir.

Beyhan ve Yazar (2017) kasidenin eğitim süreçlerinde etkin biçimde kullan1mının değerler eğitimi kapsamında öğrencilere değer bilinci kazandırmadaki öne- 
mi üzerine yapılandırdıkları çalışmalarında birer toplum mühendisi sayılabilecek şairlerin ideali yaratma ve model olarak sunmalarını sağlamada kaside örneklerinin oldukça uygun bir araç olacağını düşünmektedirler. Altun ve arkadaşlarının (2019), odağında ise bir XVIII. yüzyıl klasik Türk edebiyatı ürünü olan Hüsn ü Aşk vardır. Bu eseri değerler eğitimi açısından inceledikleri çalışmalarında eserin Millî Eğitim Bakanlığınca belirlenen değerler bakımından doyurucu bir içeriğe sahip olduğu ve bu nedenle sadeleştirilerek Türkçe ders kitaplarında okuma metni olarak yer alması gerektiği sonucuna varmışlardır. Özdemir (2019), dört örnek metin üzerinden fetihname türündeki eserlerin değerler eğitimi bağlamında kullanışlılığını açıklamak istemiş, bu aynı zamanda tarihî-kültürel vesikaların özellikle ortaöğretim düzeyinde gençlerle buluşturulmasının nesiller arasında sağlam bağlar kurulmasına imkân vereceğini ve dolayısıyla öğrencilerin tecrübenin rehberliğinden istifade edilebileceğini savunmaktadır.

Hemen hemen tüm toplumların kendi değerlerini muhafaza etmek için yeni nesillere dönük olarak türlü eğitici metinler oluşturduğunu çünkü metinlerin ve daha özelde edebî metinlerin bireyin ve toplumun değerler bağlamında bilinçlenmesinde ve değerlerin kuşaktan kuşağa aktarılmasında oldukça mühim bir işlev üstlendiğini ifade eden Iş̧1k (2019), bu amacı gerçekleştirmede çağdaş dönem yazarlarının kaleme aldığı metinler kadar bilhassa ahlaki, dinî, tasavvufî mesneviler başta olmak üzere klasik Türk edebiyatı metinlerinden de azami ölçüde istifade edilmesi gerektiğini savunmaktadır. Yok olan veya yok olmaya yüz tutmuş değerlerin yeniden yükselmesinin köklerine bağlı bir nesil kurmaktan geçtiğini düşünen araştırmacı, hipotezini XVII. yüzyıl şairlerinden Za'îfî’nin Ahbârü'l- ‘İber adlı mesnevisini inceleyerek doğrulamaya çalışmıştır. Direkci (2019), XV. yüzyılda kaleme alınan, dinî-tasavvufi muhtevalı Cevâhirü'l-Me'ânî adlı mesneviyi Millî Eğitim Bakanlığının yürürlükteki öğretim programlarında belirlediği kök değerlere dair gönderimleri açısından betimlediği çalışmasında bu değerlerden öz denetimin yirmi üç, sorumluluğun yirmi bir, sabrın on bir, sevginin dokuz, adaletin sekiz, yardımseverliğin sekiz, dostluğun altı, saygının üç, vatanseverliğin iki yerde işlendiği tespit etmiştir. Araştırmacı değer aktarımı noktasında üretken olan bu eserin sadeleştirme ve uyarlama çalışmaları sonrasında, kök değerlerin aktarımında kullanılacak kurgusal metinlerde, serbest zaman okuma metinlerinde, bilinçlenme ve farkındalık yaratma çalışmalarında ve soru köklerinde kullanılabileceği kanısındadır. Görüldüğü üzere klasik Türk edebiyatı-değerler eğitimi ilişkisinden söz açan alanyazın çalışmaları klasik Türk edebiyatı metinlerinin bu bağlamdaki engin malzemesinden yeterince istifade edilmediği ve bu edebî ekolün sağlayabileceği veri 
olanaklarından azami ölçüde faydalanılması gerektiği hususunda fikir birliği içindedir.

Holbrook'un (1998) da ifade ettiği gibi Devlet-i Aliyye'deki şiir üretimi, tarihteki en geniş edebî verim sahası olarak kabul edilebilecek kadar velut olmasına nazaran klasik Türk edebiyatı şiir envanterine dair alıntılama ve tartışma mecrası sınırlıdır. Bu araştırmanın temel amacı da atalarımızın, bizden öncekilerin, dünyayı ve hayatı anlamlandırma biçimlerini belirleyen, bizi biz yapan millî-manevi değerler ve dahası bizi insan yapan aşkın değerlere yaklaşım tarzlarını takip etmede, maziyi şimdiye ve geleceğe bağlamada klasik Türk edebiyatı metinlerinin eşsiz bir gösteren olabileceğini ortaya koymaktır. Klasik Türk edebiyatının bu yönünün örnek metinlerden hareketle altını çizmenin, onun değerler eğitimi bağlamında okuyucusu, dinleyicisi için ne kadar büyük bilgi, sezgi, fikir ve fiil olanakları sunabilecek bir potansiyele sahip olduğunu göstermek ve özellikle genç kuşaklarda ona karşı müspet bir bilinç inşa etmek bak1mından mühim olduğu değerlendirilmektedir. Ayrıca araştırmada konu edilen manzum nasihatnamelerin değer aktarımı açısından tetkik edilmelerinin eski edebî-hikemî eserlerimizin kıymetlerine yönelik bilgi ve farkındalık eksikliğini gidereceği, anlaşılmaz olduklarına dair ön yargıları kıracağı, klasik Türk edebiyatı ürünlerine dönük merak ve ilgiyi arttırma işlevi göreceğine inanılmaktadır. Netice itibarıyla böyle bir araştırmanın klasik Türk edebiyatı metinlerinin hak ettikleri itibara yeniden erişmelerini ve basılı / dijital öğretim materyallerindeki kullanım oranlarının genişlemesini sağlama noktasında etkili olacağı ve hususi olarak çocuklara seslenen manzum nasihatnamelerden oluşan yapısı ile hem eğitim paydaşlarına hem de alanyazına katkı sağlayacağı düşünülmektedir.

\section{Yöntem}

\section{Araştırmanın Modeli}

$\mathrm{Bu}$ araştırmada nitel araştırma modellerinden doküman incelemesine başvurulmuştur. Doküman incelemesi, araştırılması amaçlanan olgu veya olgular hakkında bilgi içeren yazılı materyallerin incelenmesini kapsar (Yıldırım, ve Şimşek, 2013). Doküman inceleme süreci araştırma amaç ve konusu çerçevesinde doküman taraması yapılarak başlar. Ulaşılabilirlik, orijinallik, kaynak güvenirliği, muhteva, kapsam, dil ve üslup özellikleri ölçüt alınarak, tespit edilen ve toplanan dokümanlar ile ilgili bir sinırlama yapılır. Daha sonra, belirlenen 
dokümanları itinalı bir şekilde okuma aşamasına geçilir. Bu aşamada dokümanların içerikleri çözümlenir, sınıflandırılır, düzenlenen veriler çalışmada kullanılır ve araştırma yayına dönüştürülür (Kıral, 2020).

Klasik Türk edebiyatı metinlerinin ve özellikle bu ekole ait bir edebî tür olan nasihatnamelerin öğrencilere evrensel değerleri benimsetmede önemli bir kaynak teşkil edebileceği, buna karşın yürürlükteki ortaöğretim Türk dili ve edebiyatı ders kitaplarında söz konusu edebî dönemin bu zenginliğinden yeteri kadar istifade edilmediği gözlemlenmiştir. Bu tespiti doğrulama ve problemin çözümüne dair birtakım öneriler sunma amacı mevcut ders kitaplarını ve klasik Türk edebiyatı metinlerini özenle gözden geçirme gereğini doğurmuştur. Klasik Türk edebiyatı hayli geniş bir doküman havuzuna sahip olduğundan değerler eğitimi noktasında temsil gücü yüksek bir tür olan manzum nasihatnameler üzerine odaklanılmıştır. Önce klasik Türk edebiyatı metinlerinin Türk dili ve edebiyatı ders kitaplarındaki oranı incelenmiş ve ders kitaplarında klasik Türk edebiyat1 metinlerinin alıntılanma payının oldukça düşük olduğu saptanmıştır. Daha sonra klasik Türk edebiyatı metinlerinin değerler eğitiminde ne kadar verimli bir kaynak olduğunu göstermek maksadıyla altı manzum nasihatname belirlenmiştir. Bu nasihat metinleri içerikleri bakımından tahlil edilmiş; telkinlerin muhataba aktarılmasında daha tesirli olduğu düşünülen dizeler seçilmiş, günümüz Türkçesine aktarılmış ve tematik bir sınıflandırma ile yorumlanmıştır.

\section{Evren ve Örneklem}

Araştırmada klasik Türk edebiyatı metinlerinin söylem ve anlatı zenginliği bakımından yüksek değerlerin genç kuşaklara telkininde istifade edilecek güçlü bir kaynak olduğu ve bu edebî anlayışa ait bir tür olan nasihatnamelerin doğrudan veya ima, gönderme, kıssadan hisse yoluyla muhataba ahlaki değerleri benimsetme gayesi ile yazıldığı bilgisinden hareketle nasihatname türündeki eserlerin değerler eğitimi çerçevesinde analizi yapılmak istenmiştir. Ancak Anadolu'da Yunus Emre'nin Risâletü'n-Nushiyye adlı mesnevisi ile başlayan manzum nasihatname yazma geleneğinin seyrine bakıldığında bu türe dâhil edilebilecek yüzlerce telif-tercüme metnin kaleme alındığı görülecektir hatta risale olarak kaleme alınmış, kayda geçmemiş, ismi kaynaklarda geçmekle beraber henüz bulunamamış, müstakil olmayıp divanların içerisine alınmış metinler ve dahi müteferrik beyitler, bentler de nasihatname veya nasihat içerikli dizeler olarak düşünüldüğünde bu sayı binleri bulacaktır (Emiroğlu, 2010). Bu nedenle araştırmada amaçlı (kasti) örnekleme yöntemine başvurulmuştur. Amaçlı ör- 
neklemede araştırmacı hangi dokümanların seçileceği konusunda kendi yargısı$\mathrm{n} 1$ kullanarak sorununu en iyi temsil edebilecek olan ve araştırmanın amacına en uygun olan unsurları örnekleme dâhil eder. Amaçlı örnekleme, araştırmacıların belirlenmiş, sınırları tanımlanmış bir örneklem ile çalışmak istediğinde kullanılır (Serper, Aytaç ve Bayram, 2013). Dolayısıyla bu nasihatname evreni bağlamında dönemleri için kayda değer nitelikte olan, kâmil insan ve örnek toplumun eğitimine odaklanan, latin harflerine aktarılmış, literatürde bilinirlikleri olan, manzum nasihatname türünün karakteristik özelliklerini yansıtabilen, millî-manevi ve evrensel değerlerle örtüşen pek çok ileti ihtiva eden, konu çeşitliliği bakımından zenginlik, konulara temas bakımından derinlik gösteren, farklı yüzyıllarda kaleme alınmış altı tanesi -Ahmed-i Dâ'î’nin Vasiyyet-i Nûşirevân-1 Âdil Be-Püsereş Hürmüz-i Tâcdâr'1, Şeyh Eşref b. Ahmed'in Nasihat-nâme'si, Diyarbakırlı Emîrî'nin Pendnâme-i Emîrî Çelebi'si, Nâbî'nin Hayriyye'si, Sünbülzâde Vehbî'nin Lutfiyye'si ve Ahmed Râşid'in Pend-nâme-i Lokman Hekim Terceme-i Manzumesi- araştırmanın örneklemi olarak belirlenmiştir. Bu metinlerin örneklem olarak seçilmesinde ana ölçüt, yazarlarının çocuklara hatta kimilerinde (Pendnâme-i Emîrî Çelebi, Hayriyye, Lutfiyye) kendi çocuklarına hitap etmeleridir. Ayrıca çocuğa görelik ilkesi çerçevesinde açık ve sade; mevzun, mukaffa ve musanna biçimde başka bir deyişle şiir formunda yazıya çekilmelerinden dolayı akıcı, özlü ve muhatabı üzerinde etkili bir dil ve anlatıma sahip olmaları da bu altı manzum nasihatnamenin örneklem olarak alınmasında başka bir belirleyicidir.

\section{Verilerin Toplanması ve Analizi}

Araştırma kapsamında veri toplamak üzere güncel Türk dili ve edebiyatı ders kitapları değer aktarımında klasik Türk edebiyatı metinlerine yer verme durumu çerçevesinde taranmış ve belirlenen altı manzum nasihatname metni üzerinde betimsel analiz yapılmıştır. Betimsel analizde, elde edilen veriler daha önceden belirlenen temalara göre özetlenir ve yorumlanır. Bu tür analizde amaç, elde edilen bulguları düzenlenmiş ve yorumlanmış bir şekilde ortaya koymaktır (Yıldırım, ve Şimşek, 2013).

Araştırmada Ortaöğretim Türk Dili ve Edebiyatı Dersi $(9,10,11$ ve 12. S1nıflar) Öğretim Programı'nda belirtilen kök değerlerden adalet, dürüstlük, sabır, saygı, yardımseverlik ve gerek bu değerlerle güçlü ilişkileri gerekse nasihat metinlerinde sıklıkla söz konusu edilmeleri dolayısıyla cömertlik, sözünü bilme, tokgözlülük, alçakgönüllülük ve yumuşak başl1lık değerleri hareket noktası 
alınmıştır. Bu bağlamda, sıralanan on erdemin incelenen metinlerde muhataba telkinine yönelik dizeler tespit edilmeye çalışılmıştır. Belirlenen dizeler çalışmanın kapsamı ve ayrıca metinlerin dili, ifade gücü, erdemlere yaklaşım biçimi ve bugünkü genç neslin ruh ve zihin dünyasına uygunluk ölçütleri çerçevesinde yeniden sınırlandırılmıştır. Son tahlilde bu dizeler tematik olarak sınıflandırılmış, günümüz Türkçesine aktarılarak analiz edilmiştir.

\section{Bulgular}

2020-2021 eğitim ve öğretim y1lında okutulmakta olan Türk dili ve edebiyatı ders kitaplarından 9. sınıf Türk dili ve edebiyatı ders kitaplarında yazarı belirtilerek bütünü, uzun bir pasajı veya bir yahut birkaç cümlesi / dizesi alıntılanan 310 metin içindeki klasik Türk edebiyatı metni sayısı 14'tür. İki ders kitabında alıntılanan metinler içinde klasik Türk edebiyatı örneklerinin oranı ise sadece \%4,5'tir. Öğretim Programı gereği klasik Türk edebiyatı metinlerinin daha çok yer alması gereken 10. sınıf Türk dili ve edebiyatı ders kitapları benzer yönden incelendiğinde bu kitaplardaki 179 metnin yalnızca 23'ünün başka bir deyişle \%7,7'sinin klasik Türk edebiyatı metinlerinden alıntılandığı tespit edilmiştir. Türk edebiyatı tarihinin en uzun ve en verimli dahası üretildiği zamanın ve mekânın, XIII-XIX. yüzyıl Osmanlı coğrafyasının, ruhunu en iyi temsil eden unsurlarından biri olan bir edebî cereyana ait eserlerin ders kitaplarında yeteri kadar "değerlendirilmemesi" dikkat çekici bir meseledir. Oysa sadece incelenen manzum nasihatnamelerde dahi Öğretim Programı'nda söz ve ima edilen kök değerlerden dürüstlük, adalet, sözünü bilme, yardımseverlik, cömertlik, tokgözlülük, alçakgönüllülük, saygı, sabır ve yumuşak başl1lık gibi evrensel değerin, muhataplar tarafından içselleştirilmesi ve hayatlarına, davranışlarına tatbiki ile ilgili pek çok öğüt içeriği bulunmaktadır. ${ }^{2}$

\section{Dürüst Olmak}

Ahmed-i Dâ'î muhatabına içi dışı, özü sözü bir, sade bir kişiliğe sahip olmayı tavsiye ettikten sonra düşük, kötü işlerden ve çok konuşmaktan uzak durmasını öğütler.

2 İncelenen metinlerde muhataba telkin edilen diğer evrensel değerlerden kimileri șunlardır: ağırbașll1ık (Vasiyyet-i Nûşirevân-1 Âdil Be-Püsereş Hürmüz-i Tâcdâr B 52-55), dostluk (Pend-nâme-i Lokman Hekim Terceme-i Manzumesi B 31-50), peşin hükümlü olmamak (Hayriyye B 598-607), çalışkanlık (Pendnâme-i Emîrî Çelebi B 97-99), misafirperverlik (Hayriyye B 249-259), gıybet etmemek (Şeyh Eşref b. Ahmed'in Nasihat-nâme'si B 249), komşularla iyi geçinme (Lutfiyye B 1024-1031), güler yüzlülük (Lutfiyye B 377-379), mutedil olmak (Pend-nâme-i Lokman Hekim Terceme-i Manzumesi B 103-107), alaycı olmamak (Hayriyye B 509-522), hayâ sahibi olmak (Lutfiyye B 727-729), ağzı sikı olmak (Lutfiyye B 931-936), tutumluluk (Pend-nâme-i Lokman Hekim Terceme-i Manzumesi B 95-102), affedicilik (Lutfiyye B 515-517), merhamet (Hayriyye B 231-250), tedbirli olmak (Şeyh Eşref b. Ahmed Nasihat-nâme'si B 129 ve 137). 
İçün taşun bir olsun sırf u sâde

Ne fi'lün kem ne hod kavlün ziyâde B 72

Şeyh Eşref b. Ahmed muhataba iftiracı olmaktan sakınmasını, kimseden korkmadan doğru olanın yanında bulunmasını söyledikten sonra herkesçe doğru kabul edilmesi gereken bir ilkeyi tekrar eder: Bin çomak yesen bile doğruyu diyeceksin.

İftirâ ehli olub olma helâk

Hakkı tutg1l kimseden hiç itme bâk

Emr-i ma'rûf ol durur kim hakka hak

Diyesin ger yirisen de bin çomak B 144-145

Nâbî’ye göre mert kişi yalana tenezzül etmediği gibi yalanın kötü sonucuna da tahammül etmez. Nitekim bütün işlerin bozukluğunun aslı yalandır. Şuurlu kişiler ona başvurmazlar.

Merd olan kizbe tenezzül etmez

Zillet-i kizbe tahammül itmez

Kizbdür asl-1 fesâdât-1 umûr

İrtikâb itmez anı ehl-i şuûr B 836 ve 839

Sünbülzâde Vehbî muhatabına “Çok söz yalansız olmaz.” anlayışından hareketle gereksiz ve doğal olmayan bir şekilde konuşmamasını, sözüne yalan dolan katmamasını, doğru yolda ilerlemesi gerektiğini öğütlerken bir varlığı, kişiyi veya durumu, olduğundan farklı anlatması yahut olmayan bir olayı olmuş gibi göstermesi, olmuş bir hadiseyi farklı bir açıdan yorumlaması hoş karşılanabilen şairlerin bile yalandan sakınması gerektiğini ifade eder. Ona göre yalancı, ağzından saçtığı zehirli sözlerle yılandan farksızdır. Belki de bu nedenle yalan ve yılanın yazımı benzerdir. Bir kişi için sadık, güvenilir denmesi ise büyük bir mutluluktur.

Harf-gîr olma zarâfet satma

Sözüne kizb ü dürûg1 katma 
Şâ'ir olsan da yalandan hazer et

Doğru yoldan reh-i sıdka güzer it

Dehen-i kâzib olur zehr-efşân

Birdür imlâda yalan ile yılân

Ne sa'âdet sana sâdık diyeler

Îtîmâd itmege lâyık diyeler B 390-392 ve 395

\section{Adil Olmak}

Ahmed-i Dâ'î, adaletin timsali olarak bilinen hükümdar Nuşirevan'ı konuşturarak Allah'tan kendisine kendisinden de muhataba bir öğüt emanet eder: Tüm dünyayı korunaklı, güvenli bir eve dönüştürmek, dünyada adının iyi anılmasını sağlamak ancak adaletle, herkese eşit davranmakla mümkündür. Bunu başaran kişinin adı Nuşirevan gibi şöhret bulur, ebedîleşir.

Sana benden bana Hakdan emânet

Cihânı 'adl ile dârü'l-emân it

Dürüş kim dünyede kalsun eyü ad

Anıldukça disünler âferîn bâd

Düz olsun cümle halka 'adl ü dâdun

Nuşirvân gibi meşhûr olsun adun B 19-20 ve 88

Şeyh Eşref b. Ahmed'e göre kişi her işinde adaleti gözetirse -iyi yahut kötüherkes onunla dost olacaktır.

Her işünde çünki insâf var ola

Eyü yavuz senünile yâr ola B 440

Sünbülzâde Vehbî ise kişinin, kendisine şükredilen bir kimse olmasının koşulunu başkalarına yardım etmeyi ve adil olmayı başarmasına bağlamakta ve âlemin bu yapıcı tavır sayesinde ayakta durabileceğini işaret etmektedir. 
Adl ü ihsân ile meşkûr olagör

Y1kmayup âlemi ma'mûr olagör B 770

\section{Diline Hâkim Olmak}

Ahmed-i Dâ'î'ye göre düşünmeden konuşulmamalı, söz yoruma gerek görülmeyecek kadar açık olmalı, çelişkiler içermemeli, kişinin sözü ile işi birbirine uygun olmalıdır. Dil, insanın tercümanıdır. Kişinin gönlünde ne varsa onu dil ile keşfetmek mümkündür. Sözden kötülük ortaya çıkacaksa o anda dili tutmak gerekir. İnsanda iki kulak, bir dil vardır ki bu durumun hikmetini bilen akıllı uslu kişi, sözü bir söyleyip iki dinlemelidir.

Kaçan söz söylesen fikr eyle evvel

Sözün vâzıh gerek yok kim mü'evvel

Hilâfun yog ise kavlünde lâf it

Hilâf-1 kavl ile olmaz hilâfet

Dilidür âdemînün tercümânı

Ne kim gönlinde var keşf eyler anı

Şu yirde kim gelür sözden melâlet

O yirde dilüni söyletme lâl it

Kulak iki durur âdemde dil bir

Gel imdi eyle bu hikmetde tedbir

Ki ya'nî 'akl olan uslu kişi de

Sözi bir söyleye iki işide B 37-38 ve 40-43

Kişinin neyi, ne zaman ve nasıl söylemesi gerektiğini ifade eden nasihlerden bir diğeri Şeyh Eşref b. Ahmed'tir. Ona göre kişi ne dediğini, maksadının ne olduğunu bilerek, dikkatlice demelidir. Kişi nasıl bilmediği yiyeceği yememe- 
liyse dayanaksız söz söylemekten de kaçınmalıdır. Nitekim Allah Kur'an-1 Kerim'de "Ne söylediğini bilinceye kadar namaza hiç yaklaşma." buyurmuştur. ${ }^{3}$

Söyledügün sözü bil ne söyledün

Gâfil olma maksuduna ne didün

Bilmedigün yiyeceği yimegil

Şol delilsüz sözleri söylemegil

Hakk didi çün sen sözün bilmeyesin

Sen namaza hiç yakın gelmeyesin B 106-108

Bir hususun aslını bilmeden konuşmak ateşe kül demek, sözü yerinde söylememek ise soğuktan titrerken karpuz yemek gibidir. Yerinde söylenmemiş söz ağırdır. O sözü söylemek kişiyi utandıracaktır. Dil, söz söyleme konusunda akıcı değilse konuşulmaması gerekir aksi hâlde içinde bulunulan sohbetin tadı kaçar.

Olmaya kim bilmedin söyleyesin

Şer'i budur yâ oda kül diyesin

Söylesen söyle yirinde her sözi

Ditreriken kesme zinhar karpuzı

Çün yerinde düşmedi söz bâr ola

Ol sözi söylemek anda 'ar ola

Söylemekde çün süvar degül dilün

Söyleme kim dadı gider mahfilün B 143 ve 449-451

Diyarbakırlı Emîrî’ye göre kişi her sözün içinde olmamalıdır. Zira yerli yersiz konuşan bir kişi gözüne utanç mili çekmek zorunda kalacaktır. Ayrıca bir söz nezaketten yoksunsa o sözü sarf edecek kişi tıpkı gonca gibi ağzını açmadan uygun zamanın gelmesini beklemeyi bilmelidir. Nitekim mizacında nezaketten eser olmayan bir kimsenin sözleri tatsız tuzsuzdur.

3 Nisâ Suresi, 43. ayet. 
Barmagunı katma hazer her söze

Mîl-i hacâlâtı çekersin göze

Olmaya bir söz ki nezâket-şi’âr

Açma dehânüni hazer gonçe vâr

Olmaya tab'un ki nezâket-eser

Bî-nemek olur o sözün iy püser B 110 ve 113-114

Söylenenin az ancak manasının çok olmasını ve sözün asla muhatabın gönlünü incitmemesini salık vererek özlü ve kibar konuşmanın önemini vurgulayan Nâbî’ye göre söz; gönül bağından yeni koparılmış bir gülü, onu işiten etkilenmesi ile bülbülü andırmalıdır. $O$ söz, gül gibi gönüller açmalı ve gönüllerden kinleri gidermelidir.

Lâfz1 endek ol ma’nâsı kesîr

İtmeye kimseye aslâ dil-gîr

Bâğ-1 dilden yeni kopmuş gül ola

Gûş iden vasfi ile bülbül ola

Bûy-1 gül gibi aça sîneleri

Sînelerden gidere kîneleri B 517-519

Nâbî Hayriyye'nin başka bir yerinde kişinin sözünün ne kısa ne de uzun, kararında olması gerektiğini savunur. İnsan sözünü söyleyeceği zamanı kollamalı ve onu ne hafif ne de ağır söylemelidir. İrfan nakdini teraziye koyanlar, çok sözün ancak Kur'an'a yaraştığını bildirmişlerdir. Ayrıca kişi, sözünde tekrara düşülmemelidir. Söz tekrarı ya Allah zikredildiğinde yahut ondan af dilediğinde uygundur.

İt kelâmun ne kasîr ü ne tavîl

Gözle vaktin ne hafif ol ne sakîl

Nakd-i irfânı çeken mîzâna

Didi çok söz yaraşur Kur'ân’a 
Söyledükde sözü itme tekrâr

Yâmeger zikr ola yâ istiğfâr B 613-615

Ahmed Râşid'e göre kişi söze haddini bilerek başlamalı, söze girdiğindeyse onu gereğinden fazla uzatmamalıdır. Bir insan eğer işittiklerini bir düşünce süzgecinden geçirmeden başkalarına aktarırsa dil hususuna hâkim olanlar utanacağı düzeltiler yapabilir. Düşünmeksizin söze başlanmamalı aksi hâlde kişi utanç içinde, söylediklerine pişman olacaktır. O nedenle kişi konuşmadan evvel etraflıca düşünmelidir. Ayrıca sözü gereksiz uzatarak insanları rahatsız etmemeli, söyleyeceklerini iyice hazmettikten sonra ifade etmelidir. Boş konuşmak konuşanı üzeceğinden akıllı kimseler konuşmaya sebat göstermeyi, direnmeyi, sessiz kalmayı tercih ederler.

Kendi haddin düşünüb eyle kelâma âgâz

Geçme mikdârı sakın eyleme hem nutkı dırâz

Dime halka ne işitdünse anı kı1 perhîz

Şerm-sâr itmeye tâ kim seni ehl-i temyiz

Bî- te'emmül söze âgâza cesâret itme

Sonra haclet çekerek samt u nedâmet itme

K1lub 1tnâb-1 kelâm eyleme nâsı bîzâr

Hazm ile söyle sözi gelse de vakt-i güftâr

Hele bîhûde söz itmek kılar insânı melûl

Her zamân hazm u sükût itmede erbâb-1 'ukûl B 11-15

\section{Yardımsever Olmak}

Ahmed-i Dâ'̂̂’ye göre iyi bir kişinin tüm işleri iyilik dairesinde olmalı çünkü iyi insanlar her işin iyisini yaparlar. Kişi yaptığı iyiliği duyurmak zorunda değildir, kişi iyiliğini suya salsa suyun altındaki nitelikli incilere ulaşmışçasına mutlaka kıymetli karşılıklar bulacaktır. Birisi yahut birileri iyi kişiye sı̆̆ındığında muhtaç kişi hoş tutulmalıdır. Nitekim Allah şüphesiz hoş tutanı hoş tutacaktır.

Eyü olsun işün çün sen eyüsin

Eyüler her işün işler eyüsin 
Sen eylük it suya sal kim eyüdür

Zirâ eylük iden bulmış eyü dür

Sana kim sıgnu gelse hoş dut anı

Ki Tanrı hoş dutar hem hoş dutanı B 50-51 ve 94

Şeyh Eşref b. Ahmed de muhatabına halka iyilik yapmasını, iyi insan olmasını böylece düşmanını dahi kendisine kul, dost yapabileceğini ifade eder. Ancak iyilikten anlamayana iyilik etmekte 1srarcı olunmamasını, yapılan iyiliğin başa kakılarak bozulmamasını, her insan birbirine muhtaç olabileceğinden ihtiyaç sahipleri yardım istediğinde onların hor görülmemesini tavsiye etmektedir.

Eylük itgil sen de halka eyü ol

Eylük iden itdi düşmenini kul

Eylük itme eylügi bilmeyene

Minnetile idicek yoyma yine

Horlama muhtâc olan gelse sana

Birgün ola hâcetün ola ana B 278, 435 ve 437

Fukaraya daima merhamet nazarıla bakılmasını, onlarla sert konuşulmamasını ve lütufkâr davranılmasını öğütleyen Nâbî’ye göre kişi malını muhtaçlardan esirgememeli, Allah'ın ona verdiği nimetten aç ve yoksullara yedirmelidir. Öyle ki yardımsever kişinin kapısı gelenin boş dönmeyeceği bir yer olmalı, o kapıdan mümkün olduğu kadar ihsanda bulunulmalıdır. Nabi hayırsever olmanın ehemmiyetini ortaya koymak için dikkat çekici bir dizi karşılaştırma yaparak aç doyurmanın nafile oruç tutmaktan, bir camiyi tamir ettirmekten; bir susuza su vermenin Ka'be'yi ziyaret etmekten daha hayırlı olacağını ifade etmekte, bir ihtiyaç sahibinin yüzünü güldürmenin büyük bir mutluluk, yücelik ve talih olduğunu düşünmektedir.

Fukarâya nazar-1 merhamet it

Unf ile itme Sühan mekremet it 
Bezl k1l mâlunu muhtâçlara

Ni'met-i Hakk'1 yidür açlara

Bâbınu maksad-1 dervişân it

Mümkin oldugı kadar ihsân it

Tutmadan nâfile her rûz siyâm

Hayrdur câyi'1 itmek it’âm

İtmeden yeg nice câmi' ta'mîr

Ki elünden ola bir gürsine sîr

İtmeden Ka'be'ye her sâl şitâb

Hayrdur virsen eger teşneye âb

Ne saâdet bu ne izzet devlet

Ki yüzünden güle ehl-i hâcet B 231-237

İyi insana yakışan davranış Allah'ın kullarını aç; elbise, ekmek ve yemeğe muhtaç gördüğünde ihsan kapısını açık tutmak, ihtiyaç sahiplerini bu kapıdan geri çevirmemektir.

Göricek kullarını Hakk’un aç

Câme vü nân u taâma muhtaç

Bâb-1 ihsânı sakın sedd itme

Arz-1 hâcât idicek redd itme B 249-250

Ancak ihsanda teşekküre layık olan tavır; riyakârca davranmamak, hayrı yalnızca Allah'ın bileceği gizlilikte gerçekleştirmektir. Hayır asla başa kakılmama11, ihtiyaç sahibinin utanmasına meydan vermeyecek ölçüde, âdeta utanırcasına davranılmalıdır. Hayırseverin vazifesi yardım istemekten utanan nice düşkünü arayıp bulmak olmalıdır. Bu işteki inceliğe kafa yoran kişi yaptığı ihsanın aslında kendisine döneceğini anlayacaktır. Riya ile gerçekleştirilen yardımın ne verene ne alana hayrı dokunur.

Bir teşekkür de budur itme riyâ

Fukarâya idicek lûtfu atâ 
Eyle mahfî idicek ihsânı

Hazret-i Hak bile ancak anı

İmtinân ile sakın itme 1tâb

Sen utan da o ide ref'-i hicâb

İstemekden niceler şerm eyler

Müstehakkın sen ara bul sen gönder

Eyle tahkîk bu meâniyi yyân

Sanadur her kime itsen ihsân

Olsa lütfunda ezâyile riyâ

Zâyi' olur ne sana var ne ana B 262-265 ve 269-270

Ahmed Râşid'e göre hayırsever kişi gayret nakdinin tamamını hayır işlerinde harcamalıdır ki böyle bir çaba yardım görenler açısından ortaya büyük bir fayda çıkaracaktır. Hayırlı iş, gerçekleştiğinde ümmetin faydasına neticeler vereceğinden hayırsever kişi hayırlı işler yapmak için gönülden ve çok çaba sarf etmelidir. Kişi eğer hem malıyla hem bedeniyle hayırlı iş üzere çalışırsa halk onun ismini kıyamet gününe kadar hayır ile anacaktır. Nitekim Allah insana yardımlaşarak iyi ve takva sahibi olmayı emretmiştir. O nedenle insan her yerde mesaisinin çoğunu hayra ayırmalıdır. Kişi iki dünyada da yüce mertebelere erişmek istiyorsa dünyada gücü yettiğince iyilik yapmalıdır.

Cümle hayr işde himem nakdini sarf it ey pîr

Ola hâs1l himem ü cehdin ile nef"-i kesîr

Emr-i hayra idesin ez-dil ü cân bezl-i himem

Hayr işin çünki husûlinde olur nef'-i ümem

Eyle mâlen bedenen hayr ișe cidd ü ikdâm

Yâd ide hayr ile halk ismini tâ rûz-1 kıyâm

Birr ü takvâya te'âvün ile emr itdi İlâh

Birr ü hayra kılasın bezl-i mesâ‘î her gâh 
İktidârınca cihânda hasenât it hasenât

Bulasın ‘izzet-i dâreyn ile ‘âlî derecât B 51-55

\section{Cömert Olmak}

Diyarbakırlı Emîrî’ye göre varlıklı kişi elindeki nimetleri başkaları ile bol bol paylaşmaz, onlara tabir yerinde ise şekerli şerbetler içirmezse atlastan elbisesi, samurdan kürkü dahi olsa başkalarının nazarında çulsuz görünecektir. Dolayısıyla kişi elindekileri cömertçe dağıttığı ölçüde vardır ve varlıklıdır.

Halka geh bezl olmaya ni'metlerün

İçmeyeler sükkerî serbetlerün

Sen görinürsin nazar-1 nâsa 'ûr

Câmen ola atlas ü kürkün semûr B 100-101

Başkalarını doyuran kişinin daima nimetinin bereketleneceğini, kerem edenin ikram göreceğini düşünen Sünbülzâde Vehbî, "Dişten artar." sözüyle kastedilenin ihtiyaç sahiplerini doyurmak olduğunu belirtir. Ona göre evine misafir gelen kişi sofrasını Halil İbrahim sofrasına dönüştürmelidir.

Dâ'imâ mut'îm olan mü'nîm olur

Mükrem olmaz mı o kim mükrim olur

Dişden artar dimeden asl-1 merâm

Eylemekdür fukarâyı it’âm

İdegör hânene gelse mihmân

Sofranı hân-1 Halîlü’r-Rahmân B 598-600

Sadece Ramazan ayında davet verenlerden olunmamalıdır ki insaflıca düşünüldüğünde bunun bir zevkinin olmadığı görülecektir. Cömertliğin kuralı elde bulunan nimetlerin bolca başkalarına ikram edilmesidir. Nitekim eli açıklık kişiyi yüceltir, cömert kimseler başkalarına şirin görünürler. Cimrilik eden alçak kişiler ise mallarıyla zengin olduklarını sanır hâlbuki kişinin gönlü zenginleşmedikçe mal insanı zengin kılmaz. Gençliğinde hırsı yaratılış gayesi edinen kişi 
yaşlansa da ihtirası genç kalır. Bütün dünyayı yese doymaz, tüm denizleri içse kanmaz. Böylelerinin ne kadar çok geliri de olsa fukara sayılırlar.

Olma öyle Ramazân mizyâfı

Zevki var mı idelim insâfı

Her zamân olmalıdur bezl-i ni'âm

Böyledür kâ'ide-i lutf u kerem

Sebeb-i 'izzet olur cûd u atâ

Halka şî̂n görünür ehl-i sehâ

Zinnet erbâbı olan şahs-1 denî

Zann ider kim ola mâlıyla ganî

Genc iken hırsı iden mâye-i cân

Kendisi pîr olur hırsı civân

Doyamaz yerse bütün dünyây1

Teşnedür içse dahi deryâyı

Olsa da nakd-i kesîri mevcûd

Yine anlar fukaradan ma'dûd B 614-615, 621-622, 629, 633 ve 638

\section{Kanaatkâr Olmak}

Nâbî’ye göre hırslı, açgözlü kişi rezil, alçak bir kişidir. Şerefli olmanın özü, gözü tok olmaktır. Kişi kıymetini yüceltmeli, bayağı olmamalı, bunun için de her gördüğü şeye talepkâr olmamalıdır.

Sâhib-i hırs u tama’ rüsvâdur

Kîmyâ-y1 şeref istignâdur

Âlî it kıymetüni hâr olma

Gördigün şey’e talebkâr olma B 480 ve 484 
Sünbülzâde Vehbî de benzer şekilde muhatabına açgözlü ve utanılacak hâle düşmekten sakınmasını, gönlünü zengin tutmasını öğütleyip tecrübesinden hareketle kavradığı bir gerçeği dile getirir: Tokgözlülük rızkı kendine çeker. Başka bir deyişle kanaatkâr olmak kişinin rızkını artırır. Kişi kısmetine kani olduğunda kimse onun rızkına mani alamayacaktır.

El-hazer olma gedâ-çeşm ü denî

Kalbin olsun hele gâyetde ganî

Bilirim tecrübe ile a'lâ

Câlib-i rızk idügin istignâ

Sen hemân kısmetine ol kâni’

Olamaz rızkına kimse mâni’ B 722-723 ve 752

Ahmed Râşid açgözlülüğü bir mahrumiyet / nasipsizlik tuzağ olarak değerlendirerek bu tuzağa düşenlerin üzüntü ve şeref kaybıyla perişan bir son yaşayacağı iddiasındadır. Hırsından dolayı sürekli memnuniyetsiz olan açgözlü kimse ömrü boyunca rahat ve yücelik bulamaz, buna karşın kanaatkâr, düzgün kişi bu değerli tutumu ile her an rahat yaşar. Bu hâlleriyle açgözlü kimse taneye erişmek için kümes içinde sefil yaşayan tavuğu, kanaatkâr kişi ise çölde kahkaha ile dolaşarak güzel rızıklar bulan kekliği hatırlatır. O hâlde denebilir ki Allah her ne verdiyse ona kanaat edilmelidir çünkü kişi kanaat hazinesiyle zenginlik kazanır.

Düşme dâm-1 tama'a mazhar-1 hirmân olma

Kahr u zillet çeküb encâm-1 perîşân olma

'İzz ü râhat göremez hırs ile nâlân tâmi‘

Her dem âsûde yaşar 'izz ile merd-i kâni'

Mâkiyân dâne içün oldı kümes içre sefîl

Kebk ider kahkaha sahrâda bulur rızk-1 cemîl

Her ne verdiyse Hudâ eyle kanâ‘ at zîrâ

Kişi bu kenz-i kanâ'atla ider kesb-i gınâ B 123-125 ve 152 


\section{Alçakgönüllü Olmak}

Ahmed-i Dâ'î muhatabına kibir ve ikiyüzlülükten sakınmasını, yüce Allah'tan utanarak bu kötü huylardan kaçınmasını buna karşılık doğruluk ve samimiyeti meslek edinerek tüm işlerini bu tavır üzere gerçekleştirmesini önermektedir. Ona göre kişi mütevazı olursa Allah onun tahtını, ikbalini yüceltecektir.

Sakıng1l zerk ile kibr ü riyâdan

Utan ‘izz ü celâl-i Kibriyâdan

İdingil sıdk ile ihlâsı pîşe

İşün ihlâs u sıdk olsun hemîşe

Nice kim tahtunı eyler yüce Hak

Tevâzu‘ birle olsun gönlün alçak B 75-77

Diyarbakırlı Emîrî başkalarının kibirli suçlamasında bulunmasını önlemek için muhatabına çarşıda gördüğü herkese ayrım gözetmeksizin ayrı ayrı selam vermesini öğütler. Bu hususta kişi üşengeç davranmayıp verdiği selamlarla diğer insanlara dost görünmeyi bilmelidir. Çünkü dostane tutum sergileme bağlamında elinde paylaşacak ekmeği olmayan kişi en azından tatlı diliyle başkalarına ikramda bulunmalıdır. Kişi kıymetini haddini bildiği ölçüde artıracak, kibirli olması hâlinde ise söğüt gibi baş aşağı (nitelikçe aşağıda) olacaktır.

Halka vir esvâkda bir bir selâm

Kibri sana itmeyeler ittihâm

İtme tekâsülde müdârâyı bil

Etmegün olmazsa gerek tatlu dil

Haddini bil tâ ola kadrün füzûn

Bîd gibi olmayasın ser-nigûn B 106-107 ve 144

Nâbî muhatabına makamı, mevkisi ne kadar yüksek olursa olsun kimseye el etek öptürmemesini, el etek öptürmenin erdemli kişiye yakışmayacağını, insana yaraşanın ise yüzünü yere sürmek, kibirden uzak bir tavırla hareket etmek olduğunu söylemektedir. 
Ne kadar câhun olursa âlî

Dâmenün bûseden olsun hâlî

Sana lâzım yire yüzün sürmek

Kula düşmez el etek öpdürmek B 572-573

Sünbülzâde Vehbî’ye göre kişi başkalarına daima alçakgönüllü davranmalıdır zira herkes muhatabından alçakgönüllü bir tavır umar. Yüce Allah, alçakgönüllü olanın değerini yüceltir. Kibir ve unvan peşinde koştuğu hâlde mütevazı görünen kişi ise İblis gibi ayıplanmaya layıktır.

Dâ'imâ halka tevâzu' göster

Rûy-1 dil tavrını herkes ister

Mütevâzı' olanın Rabb-i refî'

Rütbe vü kadrini eyler terfí’

Kibr ü unvân iden ehl-i telbîs

Lâyık-1 ibret olur çün İblîs B 474-476

\section{Hürmetkâr Olmak}

Şeyh Eşref b. Ahmed'e göre kişi küçükken kendisini koruyan ana babasının hakkını gözetmelidir. Nitekim evlatlarının hataları onlar için âdeta birer hünerdir ve onlar çocuklarının açlığına tokluğuna çokça özen gösterirler. Evlatları mutlu olduğunda sevinir, dertli olduğunda ise gözyaşı dökerler. İşleri evlatları için iyi olanı istemektir, gece gündüz evlatlarını düşünürler. O hâlde kişi, var olmasını sağlayan ana babasının kendisinden razı olmasını temenni etmelidir.

Zâyi' itme ata ana hakkını

Kiçilikde sakladı anlar seni

Katlarında gey hüneridi suçun

Gözedilerdi katı tokun açun

Şâd olıcak gey sevinürleridi

Dertlü olsan yaşları akarıdı 
Sana hayır sanmagıdı işleri

Gice gündüz senidün teşvişleri

Oldılar senün vücuduna sebeb

Sen de anlarun rizâsın k1l taleb B 303-307

Sünbülzâde Vehbî hoca hakkına büyük bir değer atfederek üstada çok fazla sayg1 gösterilmesi gerektiği düşüncesindedir. Nitekim ona göre oldukça ince anlamlar taşıyan "men allemeni” sözü hocaya niçin saygı duyulması gerektiğini anlatmaktadır. ${ }^{4}$ Hocasına daima bağlılık gösteren kişi her türlü sıkıntıdan kurtulur. Buna karşılık hocasına saygısızlık edenlerden huzur bulan görülmemiştir. Bir hocanın öğrencisine hayır duada bulunması o kişi için iki dünyada da murada erme vesilesidir.

Hâcene eyle begayet ta'zîm

Hakk-1 üstâd aceb emr-i azîm

Harf-i pür-nükte-i "men allemeni”

Anlatır kıldığıını bende seni

Kayd-1 mihnetden olur âzâde

Dâimâ kulluk iden üstâde

Hâceye kim iderse âzâr

Görmedik oldugını berhurdâr

Tâlibe hayr-1 duâ-yı üstâd

Dü-cihânda sebeb-i neyl-i murâd B 66-70

İhtiyarlara hürmet konusuna da değinen Sünbülzâde Vehbî muhatabına onları gördüğünde ikramda bulunmasını, bir ihtiyaçları varsa yardımda bulunmasını nasihat etmektedir. Gençleri ok ihtiyarları ise yay olarak tasavvur eden şair, okun hızlı gitmesinin yay vesilesi ile gerçekleştiğini belirtmektedir. Ona göre

4 Hazreti Ali’ye atfedilen sözün tamamı "Men allemenî harfen vekad sayyaranî abden.” (Kim bana bir harf öğretirse onun kölesi olurum.) şeklindedir. 
kişi ihtiyarlarla yakınlık kurarsa onların ögütlerinden güç alacaktır. Nitekim çoğu gönül ehli olan bu bilgili kimselerin deneyimleri faydalananlar açısından kuvvet vericidir. Feleğin yazını kışını tecrübe ederek dünyanın ne olduğunu anlamış bu insanların konuşmaları doymadan, çenelerinin düştüğünü düşünülmeden, dudă̆ 1 kurumuşlar gibi dinlenmelidir.

Göricek pîrleri ikrâm it

İhtiyâcı var ise in'âm it

Zûr-1 pervâz virür tîre kemân

Budur anla mesel-i pîr ü civân

Ya'ni pîrân ile eyle ülfet

Nush u pendinde bulursun kuvvet

Anların tecrübesi ikvâdur

Niçesi ehl- dil ü dânâdur

Germ ü serdin çekerek devrânın

Anlamış nidügini dünyanın

Nutkına teşne-leb ol kanma sakın

Gevşemişdür çenesi sanma sakın B 530-535

Ahmed Râşid muhatabından her insana değer vermesini, sevgi göstermesini özellikle de ilim erbabına hürmet göstermesini istemektedir. Ona göre ilim ve hüner sahibi kimselere hürmet gösteren kişinin yüzü, onların söz ve tavsiyelerinin gönül yaralarına merhem olması sebebiyle gülecektir.

Merdümün kadrini bil eyle muhabbet ibrâz

Bâ-husûs ehl-i ma‘ârifse anı k1l i‘zâz

Ehl-i 'ilm ü hünere hürmet iden hurrem olur

Nutk u tedbîrleri rîş-i dile merhem olur B 16-17

Büyüklerin de hürmete layık olduklarını düşünen Ahmed Râşid, gençlerden 
yaşlıları korumalarını istemektedir. Usta mimarların eski binaları yıkmak yerine onları tamir etmeyi tercih etmeleri gibi gençler de saygılı bir şekilde yaşlıların gönüllerini yapmaktan yana bir tutum sergilemelidir.

Pîrler lây1k-1 ta'zîm ri'âyet eyle

Ey civân eski müsinn zâtı himâyet eyle

Yapa gör hâtır-1 pîrânı hemân it ta'zîm

Ustalar yıkmaz ider eski binâyı termîm B 137 ve 141

\section{Sabırlı Olmak}

Ahmed-i Dâ'î'ye göre kişi öfke anında yanlış bir davranışta bulunmaktan kaçınmak için iki özelliğe sahip olmalıdır: gayet sabırlı ve yumuşak başlı olmak. Gerçek anlamda sabırlı ve yumuşak huylu kişi böyle hareket eder.

Gazab vaktinde key sabr it halîm ol

Hakîkatde sabûr oldur halîm ol B 56

Muhatabına işinde aceleci davranmamasını, her işinde daima sabır göstermesini tavsiye eden Nâbî'ye göre sabır kapı üzerinde duran, sıkıntılardan sonraki sevinç anahtarıdır. Sabır ile düşmanlar dost, yol kesiciler yol gösterici olur. Sabır, her işin düğümümü çözer. Karanlık gece bile sabrederek sabaha erişir.

Sabr k1l itme umûrunda şitâb

Sabr miftâh-1 ferecdür ber-bâb

Sabr ile dost olur düşmenler

Sabr ile rehber olur reh-zenler

Sabrdur ukde-küşâ-yı her kâr

İrişür sabr ile subha şeb-i târ B 1032-1034

\section{Yumuşak Başlı Olmak}

Nâbî muhatabına kimsenin onun yüzünden ızdırap çekmemesini, bütün dünyayı âdeta iyi huyunun esiri kılmasını öğütlemektedir. Nitekim erdemli kişi kimseye 
eziyet etmediği gibi kendisine eziyet edene dahi sert davranmaz. Doğru insan dostlarına yük olmadığı gibi kalplerini kırmaz, canını sıkmaz, gönül yıkmaz bilakis başkalarının gönlünü yapmaya çalışır. Nitekim hatır yıkmak günahların en büyüklerindendir hatta bütün günahların en kötüsüdür.

Olmasun kimse yüzünden derhem

Hulkunun bendesi olsun âlem

Cevr ile kimseyi bî-zâr itme

Sana cevr itse de âzâr itme

Yâr ol dostlarına bâr olma

Sû-i hulk ile dil-âzâr olma

Kimsenün cevr ile cânın sıkma

Hâtırın yapmağa sa’y it yıkma

Kesr-i hâtır günehün ekberidür

Cümle-i mâsiyetün bed-teridür B 537-540 ve 627

Sünbülzâde Vehbî’ye göre insaf dinin yarısıdır ve kişi tüm yapıp etmelerinde hayra yakın, insaflı ve ölçülü davranmalıdır. Allah'ın gazabına uğramak istemeyenler yumuşak huylu olmaya gayret göstermeli, hiddetli olmamalıdır.

Çünki insâf imiş nısfü'd-dîn

Munsif ü mu’tedil ol hayra karîn

Sıfat-1 hilme çalış olma gazûb

Hakk seni kılmaya tâ kim magzûb B 501-502

İncelenen nasihatnamelerde defaatle önemlerinin altı çizilen dürüstlük, adalet, diline hâkim olma, yardımseverlik, cömertlik, tokgözlülük, alçakgönüllülük, sayg1, sabır ve yumuşak başlılık gibi evrensel değerlere sahip olan insan; kıymetli, yol yordam bilen, ahlaklı, edepli insandır. Güzel ahlakıyla edebi gözeten kişilerin hayatının tazeleştiği görülecektir. Zira edep insanın süsüdür. Edep- 
siz kimse ise şeytana uyan, doğru yoldan ayrılandır (Hayriyye B 581-582). O hâlde evlada mal ve soydan daha üstün olan iyi bir terbiye verilmelidir. Sözün kısası edep, yüce ve güzel bir yaratılıştır (Şeyh Eşref b. Ahmed'in Nasihat-nâmesi B 363 ve 369).

\section{Sonuç, Tartışma ve Öneriler}

Ortaöğretim Türk dili ve edebiyatı ders kitaplarına, Öğretim Programı'nda belirtilen kök değerler (adalet, dostluk, dürüstlük, öz denetim, sabır, saygı, sevgi, sorumluluk, vatanseverlik ve yardımseverlik) ve onlarla ilişkili alt veya diğer kök değerlerin (cömertlik, sözünü bilme, tokgözlülük, alçakgönüllülük ve yumuşak başl1lık) öğrenci tutum ve davranışlarına işlenmesi gayesi ile kullanılan erdem telkin edici metin örnekleri üzerinden bakıldığında bu metinlerin yazıldıkları edebî dönem / anlayış bakımından dağılımlarında problem olduğu görülmektedir. Nitekim Türk edebiyatı tarihinin yaklaşık yedi yüz yıllık bir devresini temsil eden klasik Türk edebiyatı metinlerinin ders kitaplarında yer alma oranının bu edebî ekolün gerek ürettiği eser sayısı ve çeşitliliği gerekse Devlet-i Aliyye'nin ve dolayısıyla cetlerimizin siyasi, sosyal ve kültürel hayatı üzerindeki etkisi ve bu paradigmayı yansıtma gücü dikkate alındığında hak ettiğinden hayli düşük oranda kullanıldığı tespit edilmiştir. Elan kullanılmakta olan Millî Eğitim Bakanlığı Yayınlarından 9. sınıf Türk dili ve edebiyatı kitabında yazarı belirtilmek suretiyle tamamı, uzun bir bölümü veya kısa bir kesiti / bir ya da birkaç dizesi alıntılanan metin sayısı 143 iken bu toplam içindeki klasik Türk edebiyatı metni alıntı sayısı 3 'tür. Sonuç Yayınlarından diğer 9. sınıf Türk dili ve edebiyatı kitabında ise bu oran 167'de 11'dir. İki ders kitabında alıntılanan metinler içinde klasik Türk edebiyatı örneklerinin payı \%4,5’tir. Öğretim Programı gereği klasik Türk edebiyatı metinlerinin sıklıkla yer alması beklenen 10. sınıf Türk dili ve edebiyatı ders kitapları aynı perspektiften ele alındığında Millî Eğitim Bakanlığı yayınlarından çıkan ders kitabındaki 110 alıntının 12'sinin, Öğün Yayınlarından çıkan diğer ders kitabında ise 69 alıntının 11'inin klasik Türk edebiyatı metinlerinden olduğu, İki ders kitabında alıntılanan metinler içinde klasik Türk edebiyatı örneklerinin payının ise $\% 7,7$ olduğu görülmektedir.

Buna karşın araştırmada dikkate sunulan altı manzum nasihatname örnekleminde görüldüğü üzere klasik Türk edebiyatı dürüstlük, adalet, sözünü bilme, yardımseverlik ve yardımseverliğin bir alt değeri olan cömertlik, tokgözlülük, alçakgönüllülük, saygı, sabır ve yumuşak başlılık gibi millî-manevi ve evrensel 
değerlerin kuşaktan kuşağa nakledilmesi ve böylece erdemli insanlardan müteşekkil bir medeniyetin inşası noktasında yalnızca müstakil nasihatnameler açısından dahi irdelendiğinde benzersiz büyüklük ve derinlikte bir memba alanıdır.

Klasik Türk edebiyatı metinlerinin değerler eğitiminde kullanımı üzerine kaleme alınmış önceki çalışmalarda da Pendnâme-i Zarîfî (Akpınar, 2015), Lutfiyye-i Vehbî (Güler, 2015) gibi nasihatnamelerden; Yusuf u Züleyha (Öztürk, 2005), Hayriyye (Kayak, 2011); İskendername, Mantıku’t-Tayr, Garipnâme, Süheyl ü Nev-bahar (Sucu, 2012 ve Kurtoğlu 2016), Bûstân ve Risâletü'n-Nushiyye (Demir, 2016), Hüsn ü Aşk (Altun vd., 2019), Ahbârü'l-'İber (Işık, 2019), Cevâhirü'l-Me'ânî (Direkci, 2019), Adlî Divanı (Bayram, 2018) gibi müstakil mesnevi ve divanlardan yahut kaside gibi belirli bir nazım biçiminden (Beyhan ve Yazar, 2017) bahisle klasik Türk edebiyatı ürünlerinin değer telkini açısından kapsamlı bir içeriğe sahip olduğu ve bu içeriklerin değer aktarımını sağlamadaki derinliği örnek dizeler üzerinden defaatle vurgulanmıştır.

$\mathrm{Bu}$ araştırmalarda değerler eğitiminin, çağdaş metinler kadar klasik Türk edebiyatı ürünlerinden de sıklıkla istifade edilerek daha uygun bir biçimde aşılanabileceği ortaya konmaya çalışılmıştır (Akpınar, 2015 ve Işık, 2019), Kişiyi tanıma ve bu yolla ona rehberlik etmede yaygın olarak kullanılan terapi yöntemlerinden birinin onun çocukluğu hakkında veri toplamak olması gibi toplumdaki içkin değerlerin köklerine inmek, onların tutum ve davranışlara işleme serüvenlerini takip edebilmek için de toplumların çocukluklarına, o dönemlere dair muhtelif yaşam kesitlerini, değer yargılarını aksettiren metinlere başvurmanın doğru ve etkili bir teşhis imkânı sağlayacağı üzerinde durulmuş (Tökel, 2005), yazıldıkları devrin siyasi, idari, sosyal, ticari, hukuki, ilmî, mesleki, dinî ve ahlaki panoramasını, dolayısıyla toplumsal belleğimizi, zihin köklerimizi yansıtan klasik Türk edebiyatı metinlerinin millı̂-manevi değerlerimizin dayanaklarını sunmak bakımından eşsiz birer belge hüviyetine sahip oldukları üzerinde durularak bu tür metinlerin çocuklara millî-manevi değerlerin kazandırılmasına, çocuk eğitimine sağlayacağı katkının altı çizilmiştir (Emiroğlu, 2010). Denebilir ki Devlet-i Aliyye Dönemi sosyokültürel değerlerinin taşıyıc1s1 olarak kuşaklar arası güçlü köprüler kurulabilmesine vesile olan klasik Türk edebiyatı bu özelliği ile başı başına bir değerdir. O değer ne kadar iyi tanınır, tanıtılırsa bilişsel-toplumsal kodlarımızı kavrama ve benimseme olanağımız o kadar artacaktır. 
O hâlde klasik Türk edebiyatı metinleri ve daha özelde bir vecizeler dizisi olan nasihatnamelerin değer aktarımı hususundaki zengin malzemesi, oluşturulacak çalışma gruplarınca çocukların ilgi, merak ve ihtiyaçlarının yanı sıra dil, bilgi ve kavrama düzeylerine, başka bir deyişle çocuk gerçekliğine göre taranmalıdır. Gözden geçirme neticesinde teşekkül eden metin seçkisi daha sonra muhteva açısından sınıflandırılmalı ve bu veri madeninden, ders kitaplarındaki mevcut durumun çok üstünde bir nispette yararlanılmalıdır. Söz konusu seçki, belirli eserlerin değerler eğitimi bağlamında uygun olmayan kısımlardan arındırılarak, sadeleştirilerek (Güler, 2015; Altun vd., 2019 ve Direkci 2019) veya berceste mısralardan müteşekkil bir yapı ile (Işıksalan, 2000) bir okuma metni olarak öğrencilerle buluşturulabileceği gibi seçkideki eserlerin belirli bölümleri çeşitli etkinlik ve uygulamalarla öğretim materyallerine dâhil edilebilir (Kayak 2011 ve Taş 2016). Bu teşebbüsün, genç kuşaklar açısından en büyük tehlikelerden biri olarak duran değer yitimini önlemede, dolayısıyla kültürel dokunun sıhhat bulmasını sağlamada olumlu yönde bir tesir bırakacağı düşünülmektedir.

Edebin, edep kökünden türeyen edebiyatın klasik metinleri üzerinden telkini yeni neslin klasik Türk edebiyatı ile ilgili "anlaşılması güç edebiyat" yanılg1sından kurtulmasına, klasik metinlerimize yönelik menfi bakışın değişmesine hatta gerçekleşen farkındalıkla beraber bir hayranlığın doğmasına ve bu sayede körpe dimağlarda bir edebî zevkin inşa edilmesine katkı sağlanabilecektir. Bu yaklaşım, kuşaklar arası bağın kuvvetlenmesine, ata ile sabinin şimdi ve atide buluşmasına vesile olabilecektir. Eskilerin, tecrübelerini aktardığı metinlerin yenilere taşınması ile yenilerin söz ve alg1 dağarcıkları güçlenecek, unutulan veya unutulmaya yüz tutmuş sözlerin yeniden kullanıma girmesine yönelik yeni ve geniş bir yol açılmış olacak; genç nesil, söz varlığı güçlü bir destek noktası bulacaktır. Bu destek noktası ile bugünün çocukları hem kelime dağarcıklarını genişletecek hem de erdemli insan olmada büyük sözü dinlemenin önemini daha iyi kavrayıp istikbalin köklerde olduğu bilincine erecektir.

\section{Kaynakça}

Akpınar, Ş. (2015). Pendnâme-i Zarîfí' de yer alan değerler. International Journal of Languages' Education and Teaching, 3(1), 345-376.

Altun, K., Bekdaş, M. ve Karaoğulları, N. (2019). Hüsnü Aşk'ın değerler eğitimi açısindan incelenmesi. Turkish Studies Educational Sciences, 14(3), 303-320. 
Atalay, B. (1985). Divanü Lügati’t Türk tercümesi (Cilt 1-3). Türk Dil Kurumu.

Bayram, Y. (2012, 16-18 Kasım). Değerler eğitiminde unutulmuş bir değer: Divan şiiri ve kültürü. II. Uluslararası Değerler ve Eğitimi Sempozyumu, İstanbul.

Bayram, Y. (2018). Uluslararası Amasya şairleri bilim şöleni bildiriler kitabı. M.F. Köksal, S. Murad ve M. İlhan (Editörler), Değerler eğitimi bă̆lamında Adlî ve Dîvânı (s. 93-106). Amasya Üniversitesi.

Beyhan, E. ve Yazar, İ. (2017). Türk dili ve edebiyatı öğretim programı değerler eğitimi bağlamında "kaside". Turkish Studies International Periodical for the Languages, Literature and History of Turkish or Turkic, 12(30), 583-598.

Demir, H. (2016). Değerler eğitiminde klasik metinlerden yararlanma: Bûstân ve Risâletü'n-Nushiyye. İdil, 5(27), 2027-2046.

Direkci, B. (2019). Değerler eğitimi bağlamında Hızır bin Yakub’un Cevâhirü'l-me'ânî adlı eserinin incelenmesi. SUTAD, (45), 179-192.

Emiroğlu, S. (2010). Türkçe manzum nasihat-nâmelerin eğitim değeri üzerine bir inceleme. [Yayımlanmamış doktora tezi]. Selçuk Üniversitesi.

Güler, M.İ. (2015). Değerler eğitimi açısından Lutfiyye-i Vehbî. [Yayımlanmamış yüksek lisans tezi]. Atatürk Üniversitesi.

Holbrook, V. (1998). Aşkın okunmaz kıyıları: Türk modernitesi ve mistik romans. İletişim.

Işık, İ. (2019). Klasik Türk edebiyatında eğitim değerlerine dair bir inceleme: Ahbârü’l-‘İber mesnevisi örneği. Bitlis Eren Üniversitesi Sosyal Bilimler Dergisi, $8(1), 107-116$.

Işıksalan, N. (2000). Divân şiiri öğretimi üzerine, Milli Eğitim Dergisi, (148), 59-63.

Kaçalin, M. S. (2020). Yûsuf Hâs Hâcib: Kutadğu Bilig - metin. https://ekitap.ktb. gov.tr/Eklenti/10716,yusufhashacibkutadgubiligmustafakacalinpdf.pdf?0

Kant, I. (2020). Eğitim üzerine. (Çev: A. Aydoğan). Say.

Kaplan, M. (2001). Manzum nasihat-nâmelerde yer alan konular. Selçuk Üniversitesi Türkiyat Araştırmaları Dergisi, (9), 133-185.

Kaplan, M. (2012). Diyarbakırlı Emîrî ve nasihat-nâmesi. Uluslararası Sosyal Araştırmalar Dergisi, 5(22), 72-84.

Karaca, D., Filazi, G., Baycanlar, M., Bozbıyık, N., Çuhadar, S. (2019). Ortaöğretim Türk dili ve edebiyatı 10 ders kitabı. Millî Eğitim Bakanlığı.

Kayak, M.A. (2011). Divân edebiyatı metinlerinin ilköğretim II. kademede kullantlabilirliği ve Hayriyye-i Nâbî'nin 8. sınıf türkçe ders kitabında etkinliklerle işlenmesi. [Yayımlanmamış yüksek lisans tezi]. Erzincan Üniversitesi.

Kayaokay, İ. (2018). Ahmed Râşid'in pend-nâme-i Lokman Hekim terceme-i man- 
zumesi adlı mesnevisi. Çeşm-i Cihan: Tarih Kültür ve Sanat Araştırmaları E-Dergisi, 5(2), 71-103.

Kıral, B. (2020). Nitel bir veri analizi yöntemi olarak doküman analizi. Sosyal Bilimler Enstitüsü Dergisi, (15), 170-189.

Kurtoğlu, F.S. (2016). Çocuk edebiyatında tarihî metinlerden yararlanma: Âşık Paşa'nın Garibnâme'si. Millî Eğitim, (211), 161-186.

Millî Eğitim Bakanlığı. (2018). Ortaöğretim Türk dili ve edebiyatı dersi (9, 10, 11 ve 12. Sinıflar) öğretim programı. Millî Eğitim Bakanlı̆̆ı.

Milli Eğitim Temel Kanunu, (1973). Resmi Gazete (Sayı: 14574), https:/www.mevzuat.gov.tr/mevzuat?MevzuatNo=1739\&MevzuatTur=1\&MevzuatTertip=5.

Özcan, M. S. (2019). Ortaöğretim Türk dili ve edebiyatı 9. sınıf ders kitabı. Sonuç.

Özdemir, A. (2019). Türk edebiyatındaki fetihnâmelerin değerler ĕgitimi bakımından incelenmesi. [Yayımlanmamış yüksek lisans tezi]. Burdur Mehmet Akif Ersoy Üniversitesi.

Öztürk, M. (2019). Ortaöğretim Türk dili ve edebiyatı 10 ders kitabı. Öğün.

Öztürk, Z. (2005). On beşinci yüzyıl şairlerinden Akşemseddinzade Hamdullah Hamdi'nin Yusuf ve Zeliha mesnevisinde işlenen değerler. Değerler Eğitimi Dergisi, 3(10), 43-74.

Pehlivan, E. (2001). Şeyh Eşref b. Ahmed'in nasihat-name 'si [Yayımlanmamış yüksek lisans tezi]. Marmara Üniversitesi.

Serper, Ö., Aytaç, M. ve Bayram, N. (2013). Örnekleme. Ezgi.

Solmaz, S. (2016). Uluslararası Türk Dünyası Eğitim Bilimleri ve Sosyal Bilimler Kongresi Bildirileri. M. İskenderoğlu (Editör), Değerler ĕgitimi açısından klasik Türk edebiyatı (s. 155-169). Türk Eğitim-Sen.

Sucu, A.Ö. (2012). Mesnevilerin edebiyat eğitiminde değer aktarım aracı olarak kullanılması. [Yayımlanmamış yüksek lisans tezi]. Gazi Üniversitesi.

Sünbülzâde Vehbî. (1994). Lutfiyye. (Haz: S. A. Beyzâdeoğlu). Bedir.

Tarhan, N. (2019). Değerler psikolojisi ve insan. Timaş.

Taş, H. (2016). Mesnevî destekli değerler ĕgitiminin ilkokul 4. sınıf öğrencilerinin tutumlarına etkisi. [Yayımlanmamış doktora tezi]. Ondokuz Mayıs Üniversitesi.

Tökel, D.A. (2005). Eskilerde çocuk eğitimi: Çocuk edebiyatı gözüyle eskiye bakmak. Hece Çocuk Edebiyatı Özel Sayısı, (104-105), 76-88.

Yeniterzi, E. (2006). Ahmed-i Dâ'î’nin Vasiyyet-i Nûşirevân adlı mesnevisi. Türkiyat Araştırmaları Dergisi, (19), 1-30.

Yıldırım, A. ve Şimşek, H. (2013). Sosyal bilimlerde nitel araştırma yöntemleri. Seçkin. 
Erkan Akalin

Yücel, İ., Türkyılmaz, M. ve Sağır, S. (2019). Ortaöğretim Türk dili ve edebiyatı 9 ders kitabı. Millı̂ Eğitim Bakanlığı.

Yusuf Nâbî. (2009). Hayriyye. (Haz: İ. Pala). Kapı. 
Extended Abstract

\section{Use of Classical Turkish Literature Texts in Values Education: A Case of Poetic Nasihatname}

Erkan AKALIN, Corresponding Author, Ph.D.

Republic of Turkey Minister of National Education, Ankara / Turkey. erkan_06sebnem@hotmail.com

https://orcid.org/0000-0002-8247-5661

Article Type: Research Article

https://doi.org/10.34234/ded.816307

Received Date: 26.10 .2020

Accepted Date: 23.05.2021

Published Date: 25.06.2021

\section{Introduction}

Concepts such as justice, honesty, patience, respect, responsibility, and benevolence are universal values that all societies and individuals strive to adopt and practice most accurately and suggest to one another. Societies and individuals are aware that they can sustain their culture as long as they hold on to their values. The deprivation of these virtues is equal to the loss of cultural and humanistic identity.

Having these values empowers the society and individuals through the natural course of daily life, and ensuring that they are passed down to new generations and adopted by children using appropriate tools and methods are among the basic aims of all cultures. States follow a rather practical method to help universal values prevail in the world: placing universal values at the center of education systems and equipping this system with content and applications that refer to these values. 
When the Turkish national education system is examined in this context, the Ministry of National Education emphasizes the issue of transferring universal values to individuals and encouraging their adoption. Justice, friendship, honesty, self-control, patience, respect, love, responsibility, patriotism and helpfulness have been determined as root values in the Secondary Education of Turkish Language and Literature Course Curriculum (Grades 9, 10, 11, and 12) (2018). The curriculum is based on the principle of transferring these virtues to the students in the educational processes by handling them together with other virtues such as generosity, courage, effort, loyalty, shame, modesty, sincerity, frugality, compassion, forgiveness, sacrifice and tolerance.

Making educational processes more efficient in transferring nobel values requires making use of the texts that emphasize the importance of these virtues. One of the main sets of resource that should be reffered to is nasihatname. Many examples of such works were penned in the field of Turkish literature for guiding people to the good, beauty and righteousness, and to educate individuals who are beneficial to the society and the country. The field of Classical Turkish literature is well worth attention due to its ample examples involving advice in Turkish literature. This literary period, based on guiding its interlocutors according to Turkish-Islamic ethics, changing their attitudes and behaviors and contains hundreds of texts including advise in different volumes, forms, styles, genres and subjects, can be named as "literature of advice" or "literature of values".

The competence of classical Turkish literature in expressing the possibilities of being a perfect human and having ideal society based on high values has been the subject of many studies (Sucu, 2012; Güler, 2015; Demir, 2016; Beyhan \& Yazar, 2017; Bayram, 2018). These studies have emphasized the use of classical Turkish literature texts along with the contemporary literature texts in transferring values to new generations (Akpınar, 2015; Işık, 2019). They have pointed out the importance of bringing young generations together with the distinguished examples of classical Turkish literature, a pillar of national and moral values, so that they can establish a strong link with their past and organize their future (Işıksalan, 2000; Öztürk, 2005; Kurtoğlu, 2016). Studies argue that if these texts, which are very important in terms of children's education, are simplified and used more frequently through various activities and practices as educational materials, young generations will know classical Turkish literature more accurately and develop interest in and curiosity for this literary peri- 
od (Emiroğlu, 2010; Kayak, 2011; Bayram, 2012; Taş, 2016, Altun et al., 2019; Özdemir, 2019; Direkci, 2019). These studies also suggest that a subject under the name of "values education" should be included in the curriculum and the classical Turkish literature texts in the textbooks should be revised (Solmaz, 2016).

Classical Turkish literature texts are not sufficiently referring to the virtues in Turkish Language and Literature textbooks, and the frequency of the inclusion of the examples of classical Turkish literature in these books is rather low.

This study reveals that classical Turkish literary texts can be a unique source that help us understanding our ancestors' perspectives on the values that make us "we" and, moreover, human beings and connecting the past to the present and the future. Based on the sample texts, it is important to underline this aspect of classical Turkish literature to show how great potential it has for its interlocutors for the values education and to develop positive consciousness about it especially among young generations. The study aims to help the classical Turkish literature texts to regain the reputation they deserve and to increase the rate of their use in teaching materials.

\section{Method}

\section{Research Model}

This study utilized document analysis method, a qualitative research design. Document analysis includes the examination of written materials containing information about the phenomenon or facts aimed to be investigated (Yildırım \& Şimşek, 2013). The document analysis started by scanning the documents within the framework of the purpose of the study. The documents were limited based on some criteria such as their accessibility, originality, source reliability, content, scope, language and style features. Then, they were carefully reviewed and their contents were analyzed. The data set created was classified thematically and interpreted under the relevant titles of the study.

\section{Population and Sample}

The study aimed to analyze the nasihatname within the framework of values education. There are hundreds of texts that can be classified under the genre of classical Turkish literature; therefore, purposeful sampling method was used. In purposeful sampling, the researchers use their own judgment regarding the docu- 
ments to be selected, and include the elements that best fit their problem (Serper, Aytaç, \& Bayram, 2013). The sample included six works. Ahmed-i Dâ'̂̂'s Vasiyyet-i Nûşirevân-ı Âdil Be-Püsereş Hürmüz-i Tâcdâr', Şeyh Eşref b. Ahmed's Nasihat-nâme', Diyarbakırlı Emîrî's Pendnâme-i Emîrî Çelebi, Nâbî”s Hayriyye, Sünbülzâde Vehbî's Lutfiyye, and Ahmed Râşid's Pend-nâme-i Lokman Hekim Terceme-i Manzumesi which were significant for the period when they were written in. The works that focus on the education of individuals and establishing ideal society have been transcribed into a Latin alphabet and are known in the literature. They reflect the poetic characteristics of nasihatname style and contain many messages complying with universal values as well as being rich in diversity of subjects and deep in terms of its ties with the subjects. These texts which written in different centuries, are easy to keep in mind because they are in poetic form and most importantly, directly address children.

\section{Data Gollection and Analysis}

The current textbooks were reviewed in terms of classical Turkish literature texts for transferring values. Descriptive analysis was applied on the six poetic nasihatname within the context of data collection. In descriptive analyses, the data obtained are summarized and interpreted according to themes determined previously (Yıldırım \& Şimşek, 2013). The values justice, honesty, patience, respect, and benevolence, which are presented alongside the root values in the curriculum; generosity, silence before speech, contentedness, humility and docility - values that have strong relationship with each other and which are often mentioned in nasihatname texts-were determined as the starting point. The content of the analyzed texts was limited, classified and described within the framework of these ten values.

\section{Findings}

Ninth grade Turkish language and literature textbooks contain 310 texts, and 14 of them are classical Turkish literature texts. These texts included in two textbooks, $4.5 \%$ constitute the examples of classical Turkish literature texts Considering the 10th grade Turkish language and literature textbooks, which should include more classical Turkish literature texts according to the curriculum, which means only 23 out of 179 texts, in other words $7.7 \%$, were quoted from classical Turkish literature works. However, only the texts of poetic nasihatname include many examples of laconic expressions for root values. 


\section{Honesty}

An ideal person is the one who is straightforward. They avoid evil deeds and talking too much. They avoid being slanderous, stand by the truth without fearing anyone, keep away from telling lies even in difficult times. They know lies are the sources of disorders in all activities. A liar is no different from a snake with the poisonous words they say. Perhaps, therefore, yalan (lie) and yllan (snake) are almost homographic words in Turkish.

\section{Justice}

Turning the world into a safe place and ensuring that one's name is well known are only possible by treating everyone fairly. A just person is everyone's friend, and everyone is their friend. Order can only be achieved by adopting such an approach.

\section{Silence Before Speech}

One should not talk without thinking and the word to be uttered should be so clear that it cannot be interpreted differently. Language is the translator of man. Therefore, whatever is in people's hearts is reflected in their language. A clever person knows the reason why man have two ears and one tongue as silence is more important than speaking. Just like how people should not eat the food they do not know, they should also avoid saying the word they are not sure about. If one is not skilled at speaking, it is appropriate for them not to talk to avoid distorting the conversation.

\section{Benevolenc}

The doors of good people should always be open so that nobody will return, and they should lavish visitors with gifts as much as possible. Feeding the hungry is better than having a mosque repaired; quenching someone's thirst is better than visiting the Kaaba. A benevolent person's duty should be looking for those ashamed to ask for help. Hypocrisy does not provide anyone goodness. If one wants to attain high positions in this world and hereafter, they must do as many favors as they can in this world. 


\section{Generosity}

If a rich person does not share their blessings with others, they are regarded as poor in the eyes of others. One is only wealthy as long as they generously distribute what they have. The blessings of people feeding others always become fruitful. Even if a person who is ambitious early in life, their passion remains young. They do not get full even if they eat every food in the world, they cannot slake their thirst even if they drink all the seas. No matter how high income such people have, they are considered poor.

\section{Contentedness}

The essence of being honorable is not to be greedy. If a person wants to be a precious person, they should not be willing to obtain everything. Contentedness increases one's sustenance. When a person is satisfied with their kismet, nobody will be able to prevent their sustenance. A greedy person who is constantly dissatisfied because of their ambition cannot find comfort and glory throughout their life; a contented person is always in true comfort.

\section{Humility}

If a person is humble, God will glorify their position. Everybody seen outside should be saluted without any discrimination. One should not be timid about this, and the message of friendliness should be conveyed to other people through greetings. One will increase their value as much as they know their limits, and if they are arrogant, their head should be like the branches of the willow tree curved down to the ground.

\section{Respect}

One should always observe the rights of the parents who protect them and become happy when their children are happy; feel very sad when their children are troubled. The only thing they want is goodness of their children; they always think of their children. Respect should be paid not only to parents but also to teachers, elders, and people of knowledge and skills. A person who is always loyal to their teachers feels free from all kinds of troubles. It should be remembered that young people who are like arrows can gain speed with the help of old people who are like bows. One should establish close relationships with 
the elderly. Their advice must be listened to like the a dry lips that cracked rom thirst and need water. The ones who respects people of knowledge and skills will always be happy, thanks to their advice.

\section{Patience}

To avoid misbehavior in anger, one should have two characteristics: being patient and docile. Patience is like the key on the door for the joy that will come after troubles. With patience, enemies become friends and bandits become guides. Patience solves every problem. With patience, nights reach morning.

\section{Docility}

A virtuous person does not torment anyone, likewise they do not act harshly on those who torment them. Righteous people do not bother their friends, do not break their hearts, and try to be constructive. Upsetting or offending someone is among one of the greatest sins. One must be fair in all their actions.

\section{Conclusion, Discussion and Suggestions}

A review of the texts in Turkish language and literature textbooks showed that works of classical Turkish literature occur less frequently in textbooks when the importance of this literary period is considered. Out of 143 quotations in the 9th grade Turkish language and literature book published by Ministry of National Education (MEB) Publications, only three of them are examples of classical Turkish literature. In the textbook published by Sonuç Publications, 11 out of 167 quotations are the examples of classical Turkish literature. The classical Turkish literature examples constitute $4.5 \%$ of the texts quoted in two textbooks. In the 10th grade Turkish language and literature textbooks examples of classical Turkish literature are expected to occur more frequently in accordance with the curriculum, yet, 12 out of 110 quotations in MEB Publications and 11 out of 69 quotations in Öğün Publications are from classical Turkish literature texts. The total examples of classical Turkish constitute $7.7 \%$ of the texts in two textbooks.

The six poetic nasihatname that introduced to the readers indicate that classical Turkish literature is an unequalled source for transferring values such as honesty, justice, silence before speech, benevolence, generosity, contentedness, humility, respect, patience and docility from generation to generation and also 
a source for develoing a civilization consisting of virtuous people. Studies examining the use of classical Turkish literary texts through educational processes have always emphasized the rich content of this literary school and its strong effect on value transfer.

This literary richness of classical Turkish literature should be evaluated in terms of children education and professional working groups should be formed in this regard. The texts that light have been shed on as a result of the review should be classified in terms of content and, in educational processes, more of this data sets should be utilized. This will have a positive effect preventing the loss values, which is one of the biggest threats for young generations, and thus improving the cultural fabric of society.

Instilling good manners in new generation using classical Turkish literature texts will enable them to notice and understand this literary period in real terms. It is expected that appreciation for classical Turkish literature will emerge by raising awareness. Thanks to these quotations - legacy of our ancestors - aiming to adopt human values to their interlocutors with the help of a harmonious language. It is hoped that the perception and vocabulary of the future generation will expand as their ideas and actions rest on the knowledge and legacy of their past.

Etik Beyan / Ethical Statement: Bu çalışmanın hazırlanma sürecinde bilimsel ve etik ilkelere uyulduğu ve yararlanılan tüm çalışmaların kaynakçada belirtildiği beyan olunur. / It is declared that scientific and ethical principles have been followed while carrying out and writing this study and that all the sources used have been properly cited.

Finansman / Funding: Yazar, bu araştırmayı desteklemek için herhangi bir dış fon almadığını kabul eder. / The author acknowledges that he recevied no external funding in support of this research. 